Cilt / Volume: 2

Sayı / Issue : 2

Kiş/ Winter 2021

DS e lçu ü niversitesi

İslami İlimler Fakültesi Dergisi

\title{
Organ Nakli Konusunda İstidlal Edilen Hadisler ve Değerlendirilmesi
}

\section{Mehmet Çetin}

Dr. Öğr. Üyesi, Cumhuriyet Üniversitesi, İlahiyat Fakültesi, Hadis Anabilim Dalı Assistant Professor, Cumhuriyet University, Faculty of Theology, Department of Hadith

Sivas, Türkiye

mehmetcetin@cumhuriyet.edu.tr (iD https://orcid.org/0000-0002-3676-0912

Çetin, Mehmet, "Organ Nakli Konusunda İstidlal Edilen Hadisler ve Değerlendirilmesi”. Tevilat 2/2 (2021), 209-238. 


\section{Organ Nakli Konusunda İstidlal Edilen Hadisler ve Değerlendirilmesi}

İslam Dini, insanların hem dünya hem de âhiret saadetini sağlamayı hedefleyen bir dindir. İnsanın dünya saadeti için, beden ve ruh sağlığını korumaya yönelik bazı emirler vermiştir. Bedenini ayakta tutacak yeterli gıdayı almasını, hastalandığında iyileşmek için gerekli çabayı göstermesini emretmiştir. Akıl ve beden sağlığını korumak için içki ve uyuşturucu maddeleri kullanmasını, kendini yaralama veya intihar etme gibi sağlığına ve canına zarar verebilecek girişimleri haram kılmıştır. Hz. Peygamber'in 'günde en az beş defa alınan abdestte içinde biriken pislikleri ve mikropları temizlemek için ağız ve burnu yıkamayı, altında mikropların birikmesi nedeniyle uzadığında tırnakları kesmeyi, ağız ve diş temizliği için her namazda misvak kullanmayı (ağız ve diş temizliğini) sünnet kılması', "koruyucu hekimlik" kısmına girer. İster psiklojik hastalıklar olsun ister bedenî hastalıklar olsun "Her derdin bir devası vardır, tedavi olun. Ancak haram ile tedavi olmayın!" șeklindeki evrensel mesajı ise "tedâvî edici hekimlik" kısmına dahildir. Basit düzeyde de olsa geçmiş asırlarda organların fonksiyonlarını yitirmesi, insanı ölüme sürükleyecek seviyede iflas etmesi gibi hayatı zorlaştıran veya ölüme sebep olan durumlarda, Tıp Bilimi'nin imkanları dahilinde insana organ nakli yapılmaya başlanmıştır. Organ yetmezliği gibi sebeplerle yaşamda zorluk yaşayan veya hayati tehlikeyle karșı karșıya olan insanlara organ bağıșı yapmak, bazı İslam alimlerine göre dünyada insan canını kurtarmaya âhirette sevaba nail olmaya vesiledir. Tıp bilimini doğrudan ilgilendiren bu meselenin dini yönü ortaya konulurken hadislerden de yararlanılmaktadır. Biz bu çalışmada, organ nakliyle alakalı ilmî çalışmalarda istidlâl edilen hadisleri incelemeye ve değerlendirmeye çalışacağız. Bu çalışma bir yönüyle fikhu'l-hadîs yani hadisleri anlama, şerîi küllî kâidelerle hadislerden hüküm istinbât etmenin pratiğinin incelenmesidir.

Anahtar Kelimeler: Hadis, Fıkhu'l-Hadis, Sağlık, Tıp, Organ Nakli, Donör, Beyin Ölümü.

\section{Hadiths Deduced on Organ Transplantation and Its Evaluation}

Islam is a religion aiming to provide felicity of both life and afterlife for the people. It has given some orders to the people on protecting their physical and mental health to have felicity in this life. It has ordered them to have enough food to keep their body healthy; to make the required effort in order to get recovered. Additionally it has forbidden drinking alcohol and using drugs so as to protect their mind and body health, and the actions like committing suicide that may damage their health and life. The Prophet (his holiness)'s Sunnah, washing the mouth and nose to clean the dirt and microbes accumulated at the ritual washing at least five times a day, cutting the nails when they grow due to the accumulation of microbes under them, using the miswak (mouth and teeth cleaning) in every prayer for the hygiene of the mouth and teeth, are included within the "preventive medicine" section. His universal message that whether it is psychological or physical illness, "Every disease has its cure. Get treatment; but not with haram (the method forbidden in religion)!" is included in the scope of "therapeutic medicine". In the past centuries, with the help of limited means though, organ transplantation has started to be performed within the possibilities of Medical Science in such cases that make life difficult or cause death as loss of functions of organs or the organ failure at a level that will lead to death. According to some Islamic scholars, donating organs to people who have difficulties in life or who are in danger of death due to the reasons like organ failure, is a means of saving human life in this world and attaining merit in the life after death. While the religious aspect of this issue which directly interests the Medical Science is discussed the hadiths are consulted as well. We, in this study, will try to examine and evaluate the deduced hadiths in the scientific studies on organ donation. In one aspect, this study is an examination of the practice of fiqh al-hadith, that is, understanding the hadiths, and revealing the judgments from the hadiths with the shar'i universal rules.

Abstract Keywords: Hadith, Fiqh al-Hadith, Medicine, Organ Transplantation, Donor, Brain Death. 


\section{Giriş}

Görev yapamayacak derecede hasar gören organların yerine, canlı veya ölüden alınan yeni, sağlam organın konularak hastanın tedavi edilmesine organ nakli ya da organ transplantasyonu denir. ${ }^{1}$

İlkel düzeyde de olsa organ naklinin eskiden de uygulandığı dile getirilmektedir. Örneğin, buzağıdan dişin alınıp hacminin küçültülerek diş nakli yapıldı̆̆g, kırılan kemiğin tedavisi için kemik eklendiği bilgisi nakledilmektedir. ${ }^{2}$ Organ nakli düşüncesinin milattan önce üçüncü yüzyıla dek uzandığ ${ }^{3}$, gerçekleşmesinin 19-20. Yüzyılları bulduğu bir hakikattir. İnsanda alıcının 8 yıl daha yaşamasını sağladığı ilk başarılı organ nakli, 1954 yılında gerçekleşen böbrek naklidir. ${ }^{4}$ 19. Yüzyılda deri, 20. Yüzyılda kornea ve kan nakli uygulanmaya başlanmıştır. Beyin ölümünün keșfiyle nakledilen organ çeșitliliğ̈i artmıştır. ${ }^{5}$ Dolayısıyla organ nakli, tıp ilmindeki gelişmeler sayesinde özellikle son iki asırda daha çok uygulanmıștır. Günümüzde organ naklinin uygulanabilmesi için yasal belli kural ve şartları vardır. Örneğin, canlıdan organ nakli, alıcının en az iki yıldan beri fiilen birlikte yaşadığı eşi ile dördüncü dereceye kadar (dördüncü derece dâhil) kan ve kayın hısımlarından yapılabilir. Akraba dışı canlıdan organ nakli, naklin yapılacağı ilde oluşturulacak Etik Komisyonun verici ile alıcı arasında, ilgili yönetmeliğe, diğer mevzuata aykırı herhangi bir hususun bulunmadığını ve etik açıdan organ bağışının uygunluğunu onaylaması ile akraba dışı kişilerden yapılır. ${ }^{6}$

Hz. Peygamber "Her derdin bir devası vardir, tedavi olun. Ancak haram ile tedavi olmayın!" 7 hadisiyle bizleri tedavi olmaya teșvik etmiștir. Kadim alimlerimiz de doğrudan organ nakli olmamakla birlikte insan vücuduna müdahalenin cevazını tartışmışlar ve konuya dair görüşlerini "Buyû", "Tedâvî" ve "Izdırar Hali" gibi başlıklarda dile getirmişlerdir. Genel olarak insan vücuduna hayattayken de vefatından sonra da müdahalenin caiz olmadığına hükmetmişlerdir. Şafiî Mezhebi'nden Ebû İshâk kişinin hayatını kurtarmak için kangren olan azanın kesilmesinin câiz olduğunu söyleyerek insan vücuduna müdahalenin cevazına hükmederken, bazı Șafiî âlimler 'biraz kesilirse daha fazla kesilmeye yol açar bunun ise bir sınırı yoktur' diyerek insan vücuduna müdahalenin câiz olmadığına hükmetmişlerdir. ${ }^{8}$ Yine bazı alimler "Hamile iken

1 Esma Özşaker, "Organ Nakli ve Yaşam Kalitesi”, Balıkesir Sağlık Bilimleri Dergisi 3/3 (Aralık 2014), 166.

2 Abdunnâsır Ka'dân, "Zeru'l-A'dâi ve Ahlâkiyyeti't-Tıb min Manzûrin İslâmiyy”, İnternet Forum, http://www.ishim.net/articles.htm, ts.

3 Reşit Haylamaz, İslam Hukukuna Göre Organ ve Doku Nakli (Bursa: Bursa Uludağ Üniversitesi İlahiyat Fakültesi, 1992), 48.

4 Gülden Diniz, "Türkiye ve Dünyada Organ Transplantasyonu”, Tepecik Eğit. ve Arașt. Hast. Dergisi 29/1 (2019), 1.

5 Abdulmecid b. Muhammed es-Sebîl, el-Ahkâmu'l-Fikhiyye li-Nakli'l-A'dâi'l-İnsâniyye (Riyad: Dâru İbni'l-Cevzî, 2016), 16-17.

6 Türkiye Cumhuriyeti Sağlık Bakanlığı, "Organ ve Doku Nakli Hizmetleri Yönetmeliği”, Resmi Gazate, T.C. Cumhurbașkanlığı Mevzuat Bilgi Sistemi, 01 Șubat 2012.

7 Süleyman b. Eș'as es-Sicistânî Ebû Dâvûd, es-Sünen, thk. Muhyiddin Abdulhamid (Beyrut, ts.), Tıb 11.

8 Muhammed Ebu'l-Esâd et-Tayyib Hasen, Maksadu Hifzi'n-Nefs ve Eseruhu fí Zırâati'l-A'dâi'lBeşeriyye (Endonezya: Malang Devlet Üniversitesi, 2015), 43-45. 
vefat eden anne karnındaki ceninin hareket ettiği görülürse, anne karnının yarılıp ceninin çıkarılması gerekir. Zira Allah c.c. "... Kim de bir can kurtarırsa bütün insanların hayatını kurtarmış gibi olur..." buyurmaktadır" diyerek insan vücuduna müdahalenin caiz olduğunu dile getirmişlerdir. ${ }^{9}$

Kur'an ve Sünnet'te organ nakline doğrudan işaret eden bir delil yoktur. Sadece organı telef olan insanın vücuduna, üretilmiş (sınâî) bir organ yapılabileceğinin, modern ifadesiyle protez takılabileceğinin, cevazını gösteren şu hadis-i șerif ${ }^{10}$ vardır: "Arfece b. Es'ad'dan rivâyet edildiğine göre o şöyle dedi: "Câhiliyye döneminde Külab Günü (karışıklıklarında) burnum kesildi. Ben de gümüșten burun taktırdım. Gümüş burun koku yapınca Rasûlullah a.s. altın burun yaptırmamı emretti". ${ }^{11}$ Hadis-i şerif, insanın diş görünüşünü kötü gösteren kesilmiş organının yerine vücudundaki düzeni sağlayıp organın fonksiyonunu icrâ edecek sınâî bir organ yapılmasının dinen câiz olduğunu ifade etmektedir. Hadis-i şerif organ nakline doğrudan çözüm üretmemekle birlikte insanın maruz kaldığı zor durumlarda dinin sessiz kalmadığını ortaya koymaktadır.

Yusuf el-Karadâvî̀ye göre, organ nakli içtihâdî bir mesele olduğu için kesin kanaat belirtmek ve/veya mutlak olarak çözüm bulduğunu iddia etmek mümkün değildir. Bununla birlikte araștırmacının, genel olarak selef-i sâlihîne özelde de İmam-ı A'zam'a12 ve İmam Şâfîìye13 nispet edilen - "Görüşüm doğrudur, hatalı olma ihtimali vardır; başkalarının görüşü hatalıdır, doğru olma ihtimali vardır" sözünü söyleyebileceğini ifade eder. ${ }^{14}$ Organ naklinin cevazı konusunda üç kanaat vardır: 1- Câiz olmadığını düșünenler; 2- Câiz olduğunu düșünenler; 3Şartlı câiz olduğunu düşünenler ${ }^{15}{ }^{16}$ Doğru bir yöntem ve sahih deliller istidlâl edilerek sonuca varıldığı müddetçe içtihad içtihadı nakz etmez yani içtihad başka bir içtihad ile geçerliliğini kaybetmez. ${ }^{17}$ Ayrıca bir alim, ilmi çaba ve gayretini sergileyerek bir kanaate vardığında ulaștığı sonuç ister doğru olsun ister hatalı olsun sevabı hak eder. Nitekim Hz. Peygamber şöyle buyurmuştur: "Hâkim içtihad ederek verdiği kararda doğruya isabet ederse iki sevap kazanır; içtihad ederek verdiği kararda hata ederse bir sevap elde eder".18

9 Muhammed Ra'fet Osman, "Naklü ve Zer'ü'l-A'dâ", Zirâatü ve Maklül-A'dâ (el-Mezâhibü'lİslâmiyye ve Vahdetü'l-Ümmet, Mısır: el-Ezherü'ş-Şerîf, 2009), 2-4.

10 Abdulmecid b. Muhammed es-Sebîl, el-Ahkâmu'l-Flkhiyye li-Nakli'l-A'dâi'l-İnsâniyye, 16-17.

11 Ebû Îsâ Muhammed b. Îsâ Tirmizî, el-Câmiü's-Sahîh (es-Sünen), thk. Beșşâr Avvâd Ma'rûf (Beyrut: Dârü'l-Garbi'l-İslamî, 1998), Libâs 31; Ebû Dâvûd, Hâtem 7.

12 Fuâd b. Abdeh Ebu'l-Gays, "en-Nisbiyye ve't-Tegayyur ve Mezhebü'ş-Șekki'l-Mutlak", Mecelletü'lBeyân 213 (ts.), 27.

13 Halid Mansûr Abdullah ed-Düreys, Mevkifü'l-İmâmeyni'l-Buhârî ve Müslim min İstirâti'l-Lukyâ ve's-Semâ' fi's-Senedi'l-Mu'an'an beyne'l-Müteâsırayn (Riyad: Mektebetu'r-Rüșd, 2005), 489.

14 Yusuf Karadâvî, el-Fetâvâl-Muâsıra (Mısır - İskenderiye: Dâru'l-Vefâ, 1994), 2/530.

15 Haylamaz, İslam Hukukuna Göre Organ ve Doku Nakli, 116-122.

16 Biz konuyu organ naklini câiz görenler ve görmeyenler șeklinde iki kısma taksim ederek işledik. Zira câiz diyenler de mutlak olarak cevaz vermemekte, belli şartlar ileri sürmektedirler.

17 Ebû Bekr Ahmed b. Alî Hatîb el-Bağdâdî, el-Fakîh ve'l-Mütefekkih, ed. Ebû Abdurrahman Âdil b. Yûsuf (el-Memleketü'l-Arabiyyetü's-Suûdiyye: Dârü İbni'l-Cevzî, 2001), 2/426.

18 Ebû Abdillah Muhammed b. İsmail Buhârî, el-Camiu'l-Müsnedi's-Sahihi'l-Muhtasar min Umûri Rasûlillahi Sallâllahu Aleyhi ve Sellem ve Sünenihi ve Eyyâmih, thk. Muhammed Züheyr b. Nâsır (Mısır: Dârü Tavgü'n-Necât, 2001), el-I'ttisâm bi'l-Kitâb ve's-Sünne 21; Ebü'l-Hasen Müslim b. Haccâc el-Küșeyrî Müslim, el-Müsnedü's-Sahîhi'l-Muhtasar bi Nakli'l-Adli ani'l-Adli İlâ Rasûlillahi Sallallahu Aleyhi ve Sellem, thk. Muhammed Fuad Abdulbâki (Beyrut: Dârü Ihyâi't-Türâsi'l-Arabî, ts.), Akdiye 15. 
İslam alimleri, doğrudan işaret eden delil olmadığı için organ nakli meselesine dolaylı olarak işaret eden deliller aramışlardır. Bu çerçevede bazı hadis-i şeriflerle de istidlâlde bulunulmuştur. Biz bu çalışmada, organ nakli izah edilirken istidlâl edilen hadisleri incelemeye ve değerlendirmeye çalışacağız. Çalışmamız bir anlamda, fıkhu'l-hadis yapılarak istinbât edilen hükümlerle istidlâl edilen hadisler arasındaki uyumun irdelenmesi ve dikkatlere sunulması olacaktır.

\section{Organ Naklinin Câiz Olmadığını Kabul Eden Görüş ve Delilleri}

Muhammed b. İbrâhim Âli'ş-Şeyh, Abdülaziz b. Bâz ve Muhammed b. Useymin ve başka alimler organ naklinin câiz olmadığını düşünmektedirler. ${ }^{19}$ Kanaatlerini ispat ederken bazı hadislerle istidlâl etmişlerdir:

\subsection{Hz. Peygamber'in Müsle'yi Yasaklaması}

Hadis-i şeriflerde "Nebi a.s. (insanların mallarını) gasp etmeyi ve (organlarını keserek) müsle yapmayı yasaklamıştır" 20 ve “...müsle yapmayın..."21 buyurulmuştur. Organ nakline cevaz vermeyenler bu hadis-i şerife istinaden "Vücuttan organların kesilmesi tıpkı müsle yapmak gibidir; Rasûlullah a.s. ise müsleyi yasaklamıștır"22 demektedirler.

Öncelikle müsle ile organ nakli farklı konulardır. Müsle, öldürülen insanı aşağılamak, yakınlarını hüzne boğmak için burun, kulak gibi organlarını kesmek suretiyle yapılan ${ }^{23}$ ve herhangi bir fayda gözetilmeyen insanlık suçu iken; organ naklinde aşağılama gayesi güdülmediği gibi insanı hayatta tutmak gibi yüce bir gaye gözetilmektedir. Müsleyi yasaklayan hadis-i şerife, organların kesilmesi dikkate alınarak lafızcı, zâhirî yaklaşıldığı; Rasûlullah'ın a.s. müsleyi yasaklama sebep ve gayesinin dikkate alınmadığı görülmektedir. Bu nedenle organ naklinin câiz olmadığını ispat için bu hadisle doğru istidlâl yapılmadığı kanısındayız. Buradaki istidlâl yanlıșına "kıyâs ma'a'l-fârık" diyebiliriz. Organ naklinin müsle ile aynı șey olmadığı, aralarında çok sayıda fark olduğu ifade edilmiștir. ${ }^{24}$ Zira "Ameller niyetlere göredir. Her insan niyet ettiği şeyin karşılığını alacaktır" hadisi şerifinden istinbât edilen "الأمور بمقاصدها" yani "Bir işten maksat ne ise hüküm ona göredir" kaidesi gereğince, müsle ile organ bağışı ile icra edilen organ naklinin maksatları farklıdır. ${ }^{25}$

Bir başka rivâyette "Rasûlullah a.s. Medîne'ye geldiğinde insanlar, canlı develerin hörgüçlerini ve koyunların kuyruklarını kesiyorlardı. Bunu gören Rasûlullah a.s.:

\footnotetext{
Abdulmecid b. Muhammed es-Sebîl, el-Ahkâmu'l-Fıkhiyye li-Nakli'l-A'dâi'l-İnsâniyye, 19.

Buhârî, "Mezâlim" 31.

Müslim, "Cihâd" 3.

Abdulmecid b. Muhammed es-Sebîl, el-Ahkâmu'l-Fıkhiyye li-Nakli'l-A'dâi'l-İnsâniyye, 19.

Ebü's-Seâdât Mecdüddîn el-Mübârek b. Esîrüddîn İbnü'l-Esîr, en-Nihâye fî Garîbi'l-Hadîsi ve'l-

Eser, ed. Tâhir Ahmed ez-Zâvî (Beyrut: el-Mektebetü'l-İlmiyye, 1979), 4/294.

Haylamaz, İslam Hukukuna Göre Organ ve Doku Nakli, 65.

Arif Ali Arif el-Karadâğî, Kadâyâ Fıkhiyye fî Nakli'l-A'dâi'l-Beşeriyye (Beyrut: Dâru'l-Kutubi'lİlmiyye, 2012), 14.
} 
'Hayvan canlı iken vücudundan koparılan parça leş hükmündedir" buyurdu. ${ }^{26} \mathrm{Bu}$ hadis-i şeriften hareketle canlı varlıktan kesilen organın leş olacağını ve dolayısıyla hayatta olan insandan alınan organın naklinin câiz olmayacağını istinbât etmek doğru bir çıkarım olmaz. Çünkü hadis-i şerif hem "البهيمة yani "hayvan" kaydıyla mukayyeddir hem de organı kesmekten maksatları kesilen kısmı yemektir. ${ }^{27}$ Hayvanın vücudundan organın kesilmesi ona hem eziyet hem de tezkiye yapılmadığı için temizlenmemiş leș hükmündedir. Halbuki organ naklinde bu durum söz konusu değildir.

\section{2. Ölünün Kemiğinin Kırılmasının Dirinin Kemiğinin Kırılması Gibi Olması}

Organ nakline cevaz vermeyenlerin delillerinden bir diğeri "Ölmüş insanın kemiğinin kırılması, dirinin kemiğinin kırılması gibi günahtır" hadis-i șerifidir. ${ }^{28}$

Hadis-i şerifin de işaret ettiği üzere, organ ölen insandan nakledilse bile diriye eziyet etme gibi günah olacağından câiz değildir. ${ }^{29} \mathrm{Bu}$ kanaate, nakil esnasında donörün bedenine verilecek tahribat, ölünün kemiğinin kırılmasına kıyas edilerek varılmıştır. ${ }^{30}$ Hadis-i şerifi, "nasıl ki canlı insanın kemiklerini kırmak ona eziyet ve zulüm ise, vefat ettikten sonra da kemiğinin kırılması ona ma'nen eziyettir" şeklinde anlıyoruz. ${ }^{31}$ Zira Rasûlullah a.s. bu sözünü bir kabir kazılırken çıkan kemikleri kırmak isteyen sahâbîye söylemiş ve kemikleri kırmayıp kabrin bir kenarına toplamasını emretmiştir. ${ }^{32}$ İslam Dini, insana değer vermiş, eşref-i mahluk olarak yaratılan insanı aşağılayan, değersizleştiren davranışlar yasaklanmıştır. Bu nedenle insanın yüzüne vurmak bile haram kılınmıștır. ${ }^{33}$ Ölünün kemiğinin kırılmasında şahs-ı manevîsinin rahatsız edilmesi söz konusu iken, organ naklinde bir maslahat gözetilmektedir. Organ nakliyle sıhhatine kavuşacağı kuvvetli ihtimal dikkate alınarak zarûreten yapılan müdâhele ile hiçbir sebep ve gerekçe yokken ölünün kemiklerinin kırılması aynı şey değildir. Buradaki istidlâl yanlışına da "kıyâs ma'a'l-fârık" diyebiliriz.

\subsection{Zararın Giderilmesinin Faydanın Temininden Evla Olması}

“(Ey Âișe!) Kavmin küfürden yeni kurtulmuş olmasaydı, Kabe’yi yıkar ve onu İbrâhim'in a.s. inşâ ettiği temeller üzerine yeniden binâ ederdim"34 hadisi gibi

26 Ahmed b. Hanbel, el-Müsned, thk. Şuayb el-Arnaût - Âdil Mürşid (Beyrut: Müessesetü'r-Risâle, 2001), c. 36, 235, 21904.Hadis; Tirmizî, Sayd 12.

27 Arif Ali Arif el-Karadâĝ̂, Kadâyâ Fıkhiyye fî Nakli'l-A'dâi'l-Beșeriyye, 19.

28 Ebû Dâvûd, Cenâiz 67; Ebû Abdillâh Muhammed b. Yezîd İbn Mâce, es-Sünen, thk. Muhammed Fuâd Abdülbâkî (Kahire: Dârü'l-İhyâi'l-Kütübi'l-Arabiyye, ts.), Cenâiz 63.

29 Abdulmecid b. Muhammed es-Sebîl, el-Ahkâmu'l-Frkhiyye li-Nakli'l-A'dâi'l-İnsâniyye, 21-22.

30 Abdulmecid b. Muhammed es-Sebîl, el-Ahkâmu'l-Flkhiyye li-Nakli'l-A'dâi'l-İnsâniyye, 21-22.

31 Bedreddin Mahmûd b. Ahmed Aynî, Şerhu Sünen-i Ebî Dâvûd, ed. Ebû'l-Münzir Hâlid b. İbrâhim (Riyad: Mektebetü'r-Rüșd, 1999), c. 6, 158.

32 Abdurrahman Celâlüddin es-Süyûtî, el-Lüma' fi Esbâbi Vurûdi'l-Hadîs (Beyrut: Dâru'l-Fikr, 1996), 45.

33 Buhârî, I'tk 20; Müslim, Bir, 112, 115, 116.

34 Buhârî, Hac 42; Buhârî, Hac 400, 401. 
nasslardan süzülerek tespit edilen35 "درء المفاسد أولى من جلب المنافع", "zararların bertaraf edilmesi faydaların temin edilmesinden evlâdır" küllî kâidesi gereğince, organ nakli esnasında insan vücuduna verilecek zararın def' edilmesi gerektiği için organ nakli câiz değildir denilmiştir. ${ }^{36}$ Öncelikle organını bağışlayan kişi bu davranışıyla kendine zarar veya acı vermeyi değil başkasının acısını dindirmeyi amaçlamaktadır. ${ }^{37}$ Diğer taraftan bu kâide, maslahat ve mefsedet aynı düzeyde ise, yani kişiye eșit derecede faydası ve zararı dokunacaksa söz konusu olur ve zararın def'i evladır. ${ }^{38}$ Eğer maslahat zarardan daha ağır basarsa maslahat tercih edilir. Organ nakline cevaz verenler, nakil sebebiyle insanın sağlığına kavuşmasını bu mümkün değilse acı ve ızdırabını hafifletmeyi "zarar imkan ölçüsünde giderilir" küllî kâidesine istinaden vermektedirler. ${ }^{39}$

\subsection{Organların Satılmasının Câiz Olmaması}

Hasan Ali eş-Şâzelî, mülkiyete konu olan hayvanların alınıp satılması gibi mükerrem olan insanın alınıp satılması nasıl haram kılınmışsa, insanın organlarının satılmasının ve/veya bağışlanmasının da câiz olmadığını dile getirmektedir. Nitekim insan bedeni üzerinde ne başkası ne de kendisi tasarruf yetkisine sahip değildir. İnsan ve onun bedeni hakkında tasarruf yetkisine sadece

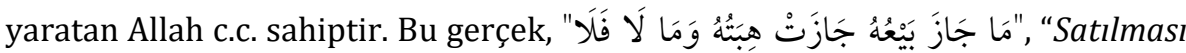
câiz olanın hibesi de câizdir; satılması câiz olmayanın hibesi de câiz değildir"40,

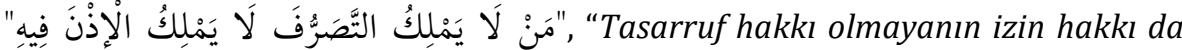

yoktur" gibi küllî kâidelerle de açıkça görülmektedir. İnsanın, organlarının satılmasının veya bağışlanmasının câiz olmadığına dair şu hadis-i şerifle istidlâlde bulunmuştur:

"Nebi a.s.'dan nakledildiğine göre O şöyle dedi: Allah c.c. şöyle buyurdu: 'Üç kişi vardır ki kıyamet gününde ben onların hasmıyım: Benim adıma yemin edip sonra sözünde durmayan kimse, hür bir kimseyi satıp parasını yiyen kişi ve bir işçiyi ücretle tutup çalıştırdığı halde ücretini vermeyen kimse.".41 Ahmed b. Hanbel (ö.241/855) ve Ebû Ya'lâ el-Mevsilî (ö.307/919) de “... Ve ben kimin hasmı olduysam klyamet günü ona hasımlık ederim" 42 ziyadesi vardır. Bu hadis-i şeriften hareketle şöyle denilmiştir: "Nasıl ki hür bir insanın köle olarak satılması ve gelirinin yenmesi haram kılınmışsa, organının satılması da haramdır. Satılması haram kılınmışsa hibe ve bağıș olarak organlarının bir başkasına verilmesi evlâ

35 Muhammed Hasan Abdülgaffâr, Usûlü I'tikâdi Ehli's-Sünneti Ve'l-Cemâa (Mevkiu'ş-Şebeketi'lİslâmiyye (http://www.islamweb.net), ts.), c. 49, 3.

Abdulmecid b. Muhammed es-Sebîl, el-Ahkâmu'l-Fıkhiyye li-Nakli'l-A'dâi'l-İnsâniyye, 25.

Arif Ali Arif el-Karadâĝ, Kadâyâ Fıkhiyye fî Nakli'l-A'dâi'l-Beșeriyye, 22.

Tâcuddin Abdulvehhab b. Tekuyyiddin es-Subkî, el-Eşbâh ve'n-Nezâir (Beyrut: Dârü'l-Kütübi'l'Ilmiyye, 1991), c. 1, 105.

39 Karadâvî, Fetevâ-i Muâsıra, c. 2, 532.

40 Hasan Ali eş-Şâzelî, Hükmü Nakli A'dâi'l-İnsân fî Fıkhi'l-İslâmi (@univeyes.ebook · İnternet Sitesi: Mektebetü Ayni'l-Câmia, tsz.), 78-81, 109-114.

41 Buhârî, Buyû' 106, İcâre 10; İbn Mâce, Ruhûn 4.

42 Ahmed b. Hanbel, el-Müsned, c. 14, 318, 8692.Hadis; Ebû Ya'lâ Ahmed b. Ali Mevsılî, el-Müsned, thk. Hüseyin Selîm Esed (Dimeşk: Dârü'l-Me'mûn li’t-Türâs, 1984), c. 11, 444, 6571.Hadis. 
olarak câiz değildir". ${ }^{43}$ Organ bağışını câiz görenler de organın bedel karşılığında satılmasını câiz görmemektedirler. ${ }^{44}$

\subsection{Hz. Peygamber'in Saç Ekletmeyi Haram Kılması}

Rasûlullah a.s. "Allah c.c. saç ekleyen (bu işi icrâ eden) ve saç ekletene lanet etmiştir" 45 hadis-i şerifinde saç ekletmeyi haram kılmıştır. Kadın saç eklettiği zaman bu genelde bașka bir kadının saçı olmaktadır. Dolayısıyla nasıl ki bir kadının saçı başka bir kadının saçına eklenmesi haramsa organ nakli de câiz olamaz. Bu istidlâle, iki durum arasında fark olmasıyla cevap verilmiştir. Zira makasıdı'ş-şerîada zaruretlerin mertebeleri değişik önceliklere sahiptir. Organ naklinin zarureti ile saç ekletmenin zaruret derecesi aynı değildir. Diğer taraftan saçı olmayan veya az olanın saç ekletmesinde kocayı (veya koca adayını) kandırma vardır/olabilir. Halbuki organ naklinde böyle bir durum olmadığı gibi mefsedeti giderme gayesi vardır. ${ }^{46}$

\section{6. Şüpheli Şeylerden Kaçınmanın Dini Bir Gereklilik Olması}

Hz. Peygamber "Helaller bellidir; haramlar da bellidir. Helal ve haramlar arasında insanların çoğunun bilmediği șüpheli şeyler vardır" 47 hadis-i şerifi ile insanları şüpheli şeylerden sakındırmıştır. Organ nakli de helal mi haram mı olduğu belli olmayan şüpheli bir durumdur. Bu nedenle kaçınılması gerekir. Bu görüş, organ naklinin şüpheli olduğunu söyleyerek tanımlama yanlışına düșmüștür. Zira organ nakli şüpheli bir şey değil, çözüm bulunması gereken içtihâdî meselelerden biridir. ${ }^{48}$ İçtihatta hata edene bir, isâbet edene ise iki sevap vardır. $^{49}$

\subsection{Organ Naklinin Îsâr Kapsamında Değerlendirilip Değerlendirilemeyeceği Meselesi}

Organ bağıșının îsâr kapsamında değerlendirilip değerlendirilemeyeceği hususunda Hasan Ali eş-Şâzelî şöyle der50: "Îsâr hakkında üç hususun öne çıktığını görüyoruz:

1-) İbâdetler hususunda îsâr yapılması mekruhtur. Örneğin, namaz vakti girdiğinde sadece kendisine yetecek kadar abdest suyu olan bir kişinin bunu başkasına vermesi mekruhtur.

43 Hasan Ali eş-Şâzelî, Hükmü Nakli A'dâi'l-İnsân fî Fıkhı'l-İslâmi, 81; Muhammed Ra'fet Osman, “Naklü ve Zer'ü'l-A'dâ", 20.

44 Karadâvî, Fetevâ-i Muâsıra, c. 2, 534.

45 Buhârî, Libâs, 81, 83; Müslim, Libâs 115, 117, 119.

46 Roumaissa Sid, Müsteciddâtü Nakli'l-A'dâi fi Manzûri'l-Fıkhi'l-İslâmî (Organ naklindeki yeni gelișmelerin İslam Hukukuna göre değerlendirilmesi) (Konya: Necmettin Erbakan Üniversitesi, 2019), 70.

47 Buhârî, İman 37, Buyû' 2; Müslim, Müsâkât 107, 108.

48 Sid, Müsteciddâtü Nakli'l-A'dâi fi Manzûri'l-Fıkhi'l-İslâmî, 70.

49 Buhârî, İ'tisâm 21; Müslim, Akdiye 15.

50 Hasan Ali eș-Şâzelî, Hükmü Nakli A'dâi'l-İnsân fí Fıkhı'l-İslâmi, 129-154. 
2-) İnsanın sahip olduğu malı, kendisi ızdırâr halinde olmamak şartıyla, ihtiyacı olmasına rağmen başkasını kendisine tercih etmesi Kur'an'ın ${ }^{51}$ ve Sünnet'in delâletiyle büyük bir fazilettir. Şu hadis-i șerif mâlî îsârın faziletini gösteren delillerden biridir: "Bir kişi Nebî a.s.'a gelerek: 'Ya Rasûlallah! Çok açım' dedi. Rasûlullah a.s. hanımlarına haber göndererek yanlarında yiyecek bir şey var mı diye sordurdu. Onlar da: 'Yanımızda sudan başka bir şey yok!' dediler. Bunun üzerine Rasûlullah a.s. adama: 'Bu gece sana yedirecek bir yiyeceğimiz yok!'buyurdu. Sonra sahabîlere dönerek: 'Kim, bu adamı bu gece misafir eder?' diye sordu. $O$ zaman Ensar'dan bir zat ayağa kalkarak: 'Onu ben misafir ederim ya Rasûlallah!' diyerek adamı evine götürdü. Ailesine: 'Rasûlullah'ın a.s. misafirine ikram et' dedi. Kadın da: 'Yanımızda sadece çocuklarımıza yetecek kadar yiyecek var!' dedi. Bunun üzerine adam: 'Kalk yemeği hazırla, kandili yak, akşam yemeği istediklerinde çocukları uyut' dedi. Bunun üzerine kadın yemeği hazırladı, kandili yaktı ve çocukları uyuttu. Sonra kadın kalkıp kandilin ışığını düzeltiyormuş gibi yaparak onu söndürdü (misafir onların da yediğini zannederek karanlıkta ortadaki yemeğin hepsini yedi ve doydu) o gece karı koca aç uyudular. (Ebû Talha) sabah olunca Rasûlullah'ın a.s. yanına gitti. Hz. Peygamber onu görünce: 'Allahu Teâlâ, bu gece yaptığınız güzel davranıştan dolayı çok hoşnut oldu.' buyurdu. Bunun üzerine Allahu Teâlâ: 'Kendileri son derece ihtiyaç içinde bulunsalar bile onları kendilerine tercih ederler' ayet-i kerimesini indirdi". ${ }^{52} \mathrm{Bu}$ hadis kendisi muhtaçken mâlî konuda bașkasını kendine tercih etmenin ne kadar faziletli olduğunu, Allah'ın c.c. böyle bir davranıştan râzı ve hoşnut olacağını göstermektedir.

3-) Îsârla alakalı üçüncü husus ise, kişinin kendi canını (veya organını) başkası için feda etmesidir. Buna şu hadis-i şerifi örnek verebiliriz: "Uhud günü insanlar savaşın şiddetinden dolayı Hz. Peygamberin etrafından dağılmışlardı. Ebû Talha r.a. Hz. Peygamberin önünde duruyor, üzerindeki deriden yapılmıș zırh ile O'na siper oluyordu. Ebû Talha çok iyi ok atıcısıydı ve yayı da çekip atmada oldukça iyi ve sağlamdı. (Buna rağmen) o gün iki veya üç yay kırdı. Rasûlullah a.s. önünden geçen sahabe-i kirâma oklarını Ebû Talha'nın önüne sermelerini emrediyordu. Ebû Talha oku attıkça Rasûlullah a.s. okun nereye gittiğini, isâbet edip etmediğini izlemek için bașını kaldırıyordu. Bunu gören Ebû Talha: 'Canım sana fedâ olsun'53 ya Rasûlallah! Mübarek bașınızı kaldırmayın. Size müşriklerin oklarından bir okun değmesinden korkuyorum. Göğsüm, sizin göğsünüze siper ve feda olsun' dedi."54

"Bu hadis ve îsarla alakalı diğer hadis-i şerifler organ bağışının cevazına delil olur mu?" sorusuna Hasan Ali eş-Şâzelî şöyle cevap vermiştir: İlgili âyet-i kerimeler ve ilk hadis, fakiri kendilerine tercih etmeleri açısından mal ile îsârı ifade etmektedir. İkinci hadis-i şerif ise cihadın mal ve can ile yapıldığını bizlere anlatmaktadır. Canı İslam için fedâ etmek yani canını İslam'a îsâr etmek, gerek hücum ederek gerekse ordu komutanını korumak için siper ederek olur. Nitekim Allah c.c. "Allah, kendi yolunda çarpışırken öldüren ve öldürülen müminlerin

Haşr 59/9; İnsan 76/8; Bakara 2/177.

Buhârî, Menâkibu'l-Ensâr 10; Müslim, Eșribe 172.

Arap kültüründe "Anam babam sana feda olsun ya Rasûlallah" ifadesinin Türkçe’ye "Canım sana fedâ olsun ya Rasûlallah" diye nakledilmesi daha doğrudur.

54 Buhârî, Menâkibu'l-Ensâr 18, Megâzî 18; Müslim, Cihâd 136. 
canlarını ve mallarını, karşılığında cennet vermek üzere satın almıştır..."55 buyurmaktadır. Dolayısıyla kişinin, cihâd meydanı dıșında, canını koruması vacip, canını tehlikeye atması haramdır. İnsan ancak İslâm'a veya Müslümanlara faydası kesin veya kesine yakın olacağında nefsini tehlikeye atabilir. ${ }^{56}$

Sünnet'e göre, kişinin hayatı ve canı söz konusu olduğunda ilk önce kendisini tercih etmesi gerekir. Hadis-i şerif şöyledir: "Uzre oğullarından bir kişi, vefatından sonra kölesinin âzâd olacağını ilan etti. Rasûlullah a.s. bu kararından haberdar olunca: 'Senin bu kölenden başka malın mülkün var mı?' diye sordu. $O$ kişi, hayır dedi. Bunun üzerine Hz. Peygamber, çevresindekilere bu köleyi kendisinden kimin satın alacağını sordu. Bir kişi sekiz yüz dirheme satın aldı. Hz. Peygamber bu parayı getirip adama verdi ve 'Malı harcamaya ilk önce kendinden başla. Eğer malın artarsa âilene harca. Âilenden bir şeyler kalırsa yakın akrabana harca. Yakın akrabandan bir șeyler kalırsa yakınlık sırasına göre harca' buyurdu". Dolayısıyla kişinin hayatıyla ilgili hususlarda ilk önce kendisini tercih etmesi gerekir. ${ }^{57}$ Organ nakline cevaz verenler de kişinin kendi hayatını tehlikeye atacak bir bağışın ve naklin câiz olmadığını dile getirmektedirler. ${ }^{58}$

\subsection{Organ Naklinin Sedd-i Zerâi` Gereği Câiz Görülmemesi}

Organ naklini câiz görmeyen bazı âlimler sedd-i zerâi' delilini de işleterek, sorundan hareketle nasslara yaklaştıkları ve hüküm istinbât ettikleri görülmektedir. Örneğin Hasan Ali eş-Şâzelî çalışmasının sonunda, organ mafyalarının yaptıkları insanlık dışı faaliyetlerden, fakir ülkelerdeki engelli çocukların organlarının organ nakli için kullanılmasından, güya medeni ve ilerlemiş milletlerin fakir ülke çocuklarını evlat ediniyormuş gibi ailelerinden satın alıp ülkelerinde son derece iyi bir bakımla büyütüp organları iflas ettiğinde de yetiştirdikleri bu çocukların organlarını kendilerine naklettirmelerinden, böbrek satış pazarı oluşmasından ve bunun için pazarlıkların yapılmasından bahsederek organ naklinin kötü emellere alet edildiğinden bahsetmekte ve "Bu davranışlar haramdır ve sedd-i zerâi' gereği harama giden yolları kapatmak gerekir" anlayışıyla organ naklinin câiz olmadığını ispat etmeye çalışmaktadır. ${ }^{59}$ İstidlâl edilen delil de yapılan istidlâl bakış açısı da doğrudur. Bu nedenle, eğer organ nakline cêvâz verilecekse, Hasan Ali eş-Şâzelî’nin dikkatimize sunduğu organ nakli hakkındaki câiz olmayan durumlara karşı çok dikkatli olmak, istismâr edilmesine firsat vermemek ve bu konudaki gerekli tedbirleri almak gerekir. Fakir çocukların, âdeta zenginlerin organ yedek parçası muamelesine tabi tutulmasına kanunen engel olunmalıdır. Diğer taraftan, sedd-i zerâi delilinin, meselenin sadece sakıncalı, problemli yönleri dikkate alınarak bu sakıncalardan uzak bir maslahatı engelleyecek șekilde işletilmemesi daha uygun gözükmektedir.

Tevbe 9/111.

Hasan Ali eș-Ŝazelî, Hükmü Nakli A'dâi'l-İnsân fî Flkhı'l-İslâmi, 151.

Hasan Ali eș-Şâzelî, Hükmü Nakli A'dâi'l-İnsân fí Flkhı'l-İslâmi, 142.

Karadâvî, Fetevâ-i Muâsıra, c. 2, 533.

Hasan Ali eş-Şâzelî, Hükmü Nakli A'dâi'l-İnsân fî Fıkhı'l-İslâmi, 157-166. 


\section{Organ Naklinin Câiz Olduğunu Kabul Eden Görüş ve Delilleri}

İnsan mükerrem ve eşref-i mahluk bir varlık olduğu için normal şartlarda canlı iken de ölü iken de vücuduna müdahale edilmesi, organlarının kesilmesi, öldükten sonra bile kemiklerinin kırılması, organlarından faydalanılması caiz değildir. Ancak zaruret durumunda durum değişmektedir. Bu nedenle "Karnında canlı halde bulunan çocuğun kurtarılması için ölü annenin karnının yarılmasına, başka yoldan tedavileri mümkün olmayan kimselerin kırılmış kemiklerinin yerine başka kemiklerin nakline, bilinmeyen hastalıkların teşhis ve tedavilerinin sağlanabilmesi için, yakınlarının rızası alınmak suretiyle, ölüler üzerinde otopsi yapılmasının caiz olacağına fetva vermişler; canlı bir kimseyi kurtarmak için, ölünün vücut bütünlüğüne müdahale etmeyi caiz görmüşlerdir. Aynı şekilde açlık ve susuzluk gibi, hastalığı da haramı mübah kılan bir zaruret saymışlar, başka yoldan tedavileri mümkün olmayan hastaların haram ilaç ve maddelerle tedavilerini caiz görmüşlerdir. Günümüzde kan, doku ve organ nakli, tedavi yolları arasına girmiş bulunmaktadır". ${ }^{60} \mathrm{Bu}$ meselelere hüküm verirken mecelle kaidesi olan "Zarûretler haramları mubah kılar" ilkesinden de yararlanılmıștır. ${ }^{61}$ Ancak ilgili maddenin tüm haramları helal hale getirdiği düşünülmemelidir. Zira günahsız bir kimsenin öldürülmesi gibi bazı haramların haramlık vasıfları hiçbir şekilde düşmez ve bunların işlenmesi mübah hale gelmez. ${ }^{62}$

Organ bağışlama veya bağışlanmasını vasiyet etme meselesi "maslahatı celb ve mefsedeti def"' prensibine göre çözülür. Buradan hareketle zann-ı galibe göre maslahat yönü ağır basarsa câiz olduğuna, mefsedet yönü ağır basarsa câiz olmadığına hükmedilir. Zira şerî̂ kâideler canın korunmasını emretmektedir. Maslahat ağır bastığı için mefsedetin dikkate alınmadığı çok sayıda hüküm vardır. ${ }^{63} \mathrm{Bu}$ nedenle gerek donörden organın alınması gerekse organın bağışlandığı kişiye nakli esnasında ameliyatın başarılı olacağına dair kanaatin kuvvetli olması gerekir. $\mathrm{Bu}$ çerçevede doktorların Müslüman olması şart koşulmasa da adil iki doktorun şehâdeti şart koşulmuştur. Bu şart hem Kur'an ${ }^{64}$ hem de sünnet nasslarına dayanılarak konulmuştur. Hadis-i şerifte "Üç şey vardır ki ciddisi de ciddidir, şakası da ciddidir: Nikah (Evlenme), Talak (Boşama) ve Ric'at (Boșamadan vazgeçip eșine dönme)"65 buyurulmuştur. Nikah önemli hâdiselerden olduğu için "Velî ve iki âdil şâhit olmadığı sürece nikah geçerli

60 Diyanet İşleri Başkanlığı Din İşleri Yüksek Kurulu, Fetvalar (Ankara: Diyanet İşleri Başkanlığı Yayınları, 2018), 523-525.

61 Mehmet Şener, “İslam Hukukuna Göre Organ Nakli Üzerine Bir Deneme”, Dokuz Eylül Üniversitesi İlahiyat Fakültesi Dergisi 7 (1992), 140.

62 Merve Özdemir, İslam Hukukuna Göre Beden Üzerinde Tasarruf ve Organ Nakli (Sakarya Üniversitesi, 2017), 120.

63 Muhammed Rașid Kubbânî, “Zırâatü'l-A'dâi'l-İnsaniyye fî̀ Cismi'l-İnsan”, Mecelletü'l-Mecmei'lFıkhi'l-İslâmî 1/1 (2003), 55-65.

64 Bakara 2/282; Hucurât 49/6.

65 Ebû Dâvûd, Talak 10; Tirmizî, Talak 9; İbn Mâce, Talak 13. 
olmaz"66 buyurulmuştur. Bu hadis-i șerifin senetleri zayıf olarak kabul edilse de ${ }^{67}$ Kur'an ve Sünnet delillerini bütüncül düşündüğümüzde toplumda niza' ve tartışmaya, hak mahrumiyetine sebep olacak, geri dönülmesi ve telafisi mümkün olmayacak konularda şahit tutulması, bu şahitlerin de âdil, güvenilir insanlardan seçilmesi en azından tavsiye ve irşâd kabilindendir. Buna kıyasen, önemli bir olay olan organ nakli konusunda da âdil doktorların naklin uygunluğunu beyanları aranır. Zira tıp bilgilerine, alanlarındaki ehliyet ve liyakatlarına, güvenilir ve sağlam şahsiyetlerine itimat edilen doktorların beyanları, insanların içinde huzur ve güveni doğurur; donörün ve kendisine nakil yapılacak insanların bağış ve nakilden sonra gerçekleşebilecek ani sağlık bozulmalarında (komplikasyonlarda) bunun doğal olduğunu kabul etmelerini sağlar. Beyin ölümü konusunda da zikredileceği üzere, bir kişinin beyin ölümü gerçekleştiğine ancak iki farklı branșta uzman doktorun karar vermesi nasıl yasal bir zorunluluksa, organ naklinin de başarılı olup nakledilen insana uyum sağlayacağı ve onun sağlığını artıracağı hususunda adil doktorların zann-1 galibinin olması gerekir.

Haklar dörde ayrılır: 1-) Sadece Allah'a ait olan haklar. 2-) Sadece kula ait olan haklar. 3-) Allah'ın ve kulun hakkı bir arada olmakla beraber Allah'ın hakkının ağır bastığı haklar. 4-) Allah'ın ve kulun hakkı bir arada olmakla beraber kulun hakkının ağır bastığı haklar. ${ }^{68}$ Bu çerçevede Allah c.c. - Allah hakkı ile kul hakkı bir arada bulunmakla beraber - kul hakkının ağır basması sebebiyle yaralama veya katl durumlarında kısası veya diyeti yahut da diyeti de istemeyip affetmeyi tercih edip etmeme salahiyetini kuluna bırakmıştır. Organ naklinde de "Organını bağıșlama veya bağıșlanmasını vasiyet etme meselesi kulun kendine âit haklardandır. Bedeninde mutlak olarak, sınırsız bir şekilde dilediği gibi tasarruf etme hakkına sahiptir." deme şansına sahip değiliz. Zira canın korunması zarûrât-ı hams dediğimiz (din, can, mal, ırz ve akıl olmak üzere) korunması gereken beș șeyden biridir. Bu sebeple - daha sonra ișleneceği üzere - insanın intihar etmesi yasaklanmıştır. Şu halde organ nakline cevaz veren âlimlerin dayandıkları hadisler nelerdir? Yaptıkları istidlâl doğru ve tutarlı mıdır? Bu kısımda da bu soruların cevabını aramaya çalıșacağız.

\subsection{Merhametin Sâikiyle Organ Bağışlamanın Allah'ın Rahmetini Celbedeceği Düşüncesi}

Hz. Peygamber, "Allah merhametli kullarina merhamet edecektir. Siz yeryüzündekilere merhamet edin ki Allah da size merhamet etsin..."

\footnotetext{
66 Abdürrezzâk Ebû Bekir b. Hemmâm San'ânî, el-Musannef, thk. el-A'zamî Habîbürrahmân (Beyrut: el-Mektebü'l-İslamî, 1983), c. 6, 195, 10473; Ebû Bekir Abdullah b. Muhammed İbn Ebî Şeybe, elMusanneffi'l-Ehâdîs ve'l-Âsâr, thk. Kemâl Yûsuf el-Hût (Riyâd: Mektebetü'r-Rüşd, 1989), c. 3, 455, 15934.Hadis; Ebû Osmân Saîd b. Mansûr, Sünen-i Saîd b. Mansûr, ed. el-A‘zamî Habîbürrahmân (Hindistan: ed-Dâru's-Selefiyye, 1982), c. 1, 178, 544. Hadis.

67 Ahmed b. Hanbel, el-Müsned, c. 40, 247, 24205 (Bkz. Şuayb el-Arnaût'un dipnotta yaptığı açlklama).

68 Alâuddin Abdulaziz b. Ahmed Abdulaziz el-Buhârî, Keșfü'l-Esrâr Şerhu Usûli'l-Pezdevî (Mısır Kahire: Dâru'l-Kitâbi'l-İslâmî, ts.), c. 4, 134.
} 
buyurmaktadır. ${ }^{69}$ Yusuf el-Karadâvî de, merhamet sebebiyle yapılan organ bağışının Allah'ın rahmetini celb edeceği için dinen caiz hatta teşvik edilmesi gereken bir davranış olduğunu dile getirmektedir. Bu nedenle "Hayatta olan bir kișinin sağlıklı olan iki böbreğinden birini bir bașkasına bağıșlaması caizdir hatta övülen bir davranıştır ve sevabı hak eder" der. "İnsanın, boğulan bir kişiyi kurtarmak için suya dalarak, yanan kişiyi kurtarmak ve/veya yangını söndürmek için ateşe girerek kendini tehlikeye atması nasıl ki meşru' (dinen câiz) ise, hayatta iken (kendi sağlığını tehlikeye atmayacak çift organlarından bir) organını bağışlayarak kendini tehlikeye atması neden meşru' olmasın?!" der. ${ }^{70}$ Diğer taraftan "Komşusu açken tok yatan kâmil mü'min değildir"71 ilkesini öğreten ve açlık için böyle söyleyen bir din, hastalık sebebiyle kıvranana yardım hususunda bigane kalınmasına onay verebilir mi? ${ }^{72}$ Hadis-i șeriflere yapılan fıkhu'l-hadisin ve yapılan istidlâlin isâbetli olduğu kanaatindeyiz. Bu sonuca ulaşırken, "iki böbreği de sağlıklı olduğu için birini bağışladığında kendi vücut fonksiyonları kayba ve zarara uğramayacak" olması şartı önemlidir. Nitekim kendini zarara sürükleyeceği kesin olan hatta ölümüne sebep olacak bir bağışın ve naklin câiz olmadığını dile getirmektedir. ${ }^{73}$

\subsection{Organ Bağışının Sadaka Olarak Kabul Edilmesi}

Rasûlullah a.s. çaresiz ve yardıma muhtaç insanlara yardım etmenin ve her türlü iyiliğin sadaka olduğunu şu sözleriyle haber vermiştir: "Hz. Peygamber 'Her Müslümanın sadaka vermesi gerekir' buyurdu. 'Sadaka verecek bir şey bulamazsa?' dediler. 'Çalışır (kazanır) hem kendisine faydalı olur hem de tasadduk eder' buyurdu. 'Buna da gücü yetmezse?' dediler. 'Darda kalana, ihtiyaç sahibine yardım eder' buyurdu..."74; "Her iyilik sadakadır"75. İlk hadis-i șerifte geçen "zor durumda olan muhtaç" ifadesinin umûmuna, hastalığı sebebiyle ızdırap çeken kimse de dahil edilmiştir. Bu çerçevede Yusuf el-Karadâvî, İslam'ın sadakayı sadece mal ile sınırlandırmadığını, yapılan her iyiliğin bir sadaka olduğunu söyleyerek $\mathrm{Hz}$. Peygamberin hadis-i şerifine işaret etmiștir. Dolayısıyla organ nakli bir iyilik olması açısından sadakadır. Hatta mal ile yapılan sadakadan daha üstündür. Zira insan sahip olduğu en değerli şeyi, vücudundan bir parçayı başkasına bağışlamaktadır. Sadaka İslam'ın teşvik ettiği ve âhirette insanın kurtuluşuna vesile olacak bir davranıştır. ${ }^{76}$ Diyanet İşleri Eski Başkanı Prof. Dr. Mehmet Görmez'in "Organ bağıșı, candan cana yapılacak en büyük sadakadır" sözü de dini hizmetlerden sorumlu Diyanet İșleri Başkanlığı'nın ve burayı temsil eden

69 Tirmizî, el-Bir ve’s-Sıla 16; Ebû Dâvûd Süleyman b. Dâvûd Tayâlisî, el-Müsned, thk. Muhammed b. Abdülmühsin et-Türkî (Mısır: Dârü Hicr, 1999), c. 1, 362, 333.Hadis.

Karadâvî, Fetevâ-i Muâsıra, c. 2, 532.

71 İbn Ebî Şeybe, el-Musannef, c. 11, 24, 30996.

72 Hikmet Akdemir, “Organ Naklinin Kur’an Açısından Değerlendirilmesi”, Harran Üniversitesi Illahiyat Fakültesi Dergisi 14 (2005), 12.

Karadâvî, Fetevâ-i Muâsıra, c. 2, 533.

74 Buhârî, Zekat 30, Edeb 33; Müslim, Zekat 55.

75 Buhârî, Edeb 35; Müslim, Zekat 52.

76 Karadâvî, Fetevâ-i Muâsıra, c. 2, 532. 
Başkan'ın da organ bağışını sadaka olarak kabul ettiğini göstermektedir. ${ }^{77}$ Hadis şerhlerine baktığımızda hayır ve iyilik konuları işlenirken "hayır (iyilik) yapın"78 âyeti ${ }^{79}$ ve "iyilik ve takvâda yardımlaşın"80 âyeti ile 81 "her iyilik sadakadır" hadisinin birlikte verildiğini görüyoruz. Bu durum ilgili âyet ve hadislerin umûm ifade eden bir lafız olduğunu, ma'ruf kapsamına giren şeylerin tamamını içine alabileceğini göstermektedir. ${ }^{82}$ Ma'rûf ise hayır yapmaktır ve yapılması vacip değildir. ${ }^{83}$ Râgıb el-İsfehânî (ö.502/1109) ma'rûfu "hüsnü (güzelliği, doğruluğu) şer'an ve aklen bilinen şey" olarak tarif ederken ${ }^{84}$, Kadı Iyâz (ö.544/1149) ise ma'rûf kelimesinin Şâri'in ıstılahında, "hüsnü şer'an bilinen şey" 85 olduğunu dile getirmektedir. Dolayısıyla kişinin kendi bedenine zarar vermeyecek organ bağışı, merhametten kaynaklanarak başkasının çektiği acı ve ızdırabı dindirmek, hayatta kalmasını sağlamak için yapılıyorsa bu bir ma'ruftur, İslam Dini ve akıl yoluyla hüsnü kabul edilen bir davranıştır. Ma'rûf'un her türlüsü de sadaka olması hasebiyle dinen teşvik edilen bir davranış olmaktadır.

\subsection{Organ Bağışının Mü'minin Sıkıntısını Gidermek Kapsaminda Kabul Edilmesi}

Hz. Peygamber bir hadisinde "Kim bir mü'minin dünya sıkıntılarından bir sıkıntısını giderirse Allah c.c. da onun Kıyâmet Günü sıkıntılarından bir sıkıntısını giderir. Bir kimse darda kalana kolaylık gösterirse, Allah da ona dünya ve âhirette kolaylık gösterir. Bir kimse, bir Müslümanın ayıbını örterse, Allah da onun dünya ve âhiretteki ayıplarını örter. Mü'min kul, din kardeşine yardım ettiği sürece, Allah da o kula yardım eder" buyurmaktadır.86 Mü'minden bir sıkıntının giderilmesi, Allah'ın o kulunun âhiret sıkıntılarını gidermesine vesiledir. Bu çerçevede organ bağışı, bedenî rahatsızlık sebebiyle acı ve ızdırap çeken bir kişinin sıkıntısını gidermek olacağı için bu hadisin kapsamına girer. ${ }^{87}$

Allah Rasûlü bir başka hadisinde şöyle buyurmuştur: “Müminler, birbirlerini sevmede, birbirlerine merhamet ve şefkat göstermede, tıpkl bir organı rahatsızlandığında diğer organları da uykusuzluk ve yüksek ateşle bu acıyı

77 Macit, Mustafa, Öztaş Fatih, “'Kalbinize Bir Sorun Hayat Vermek İster mi?' Kadavradan Organ Nakli ile İlgili Tutumlar, Tıp ve Toplum (İnternet Gazete Haberleri Üzerinden Bir İnceleme)”, ILTED (İlahiyat Tetkikleri Dergisi) 1/45 (2016), 35. el-Hac $22 / 77$.

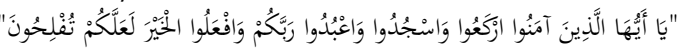

Ebû Ömer Cemâlüddîn Yûsuf b. Abdillâh en-Nemerî İbn Abdülber, et-Temhîd Limâ fi'l-Muvatta, thk. Mustafa b. Ahmed el-Alevî - Muhammed Abdülkebîr (Mağrib: Vizâratü 'Umûmi'l-Evkâf ve'şŞuûni'l-İslamiyye, 1967), c. 16, 345.

Ebü'l-Ferec Cemâlüddîn Abdurrahman b. Ali İbnü’l-Cevzî, Keșfü'l-Müşkil min Hadisî's-Sahîhayn, ed. Ali Hüseyn el-Bevvâb (Riyâd: Dâru'l-Vatan, ts.), c. 1, 395, 349.Hadis.

Ebü’l-Kāsım Hüseyn b. Muhammed Râgıb el-İsfahânî, el-Müfredât fí Garîbi'l-Kur'an, ed. Safvân Adnân ed-Dâvudi (Dımașk - Beyrut: Dâru'l-kalem - Dâru'ş-Şâmiye, 1992), 561.

Muhammed Abdürraûf Münâvî, Feyzü'l-Kadîr Serhü Câmii's-Sağîr (Mısır: Mektebetü'tTicâriyyeti'l-Kübrâ, 1938), c. 5, 33.

Müslim, Zikir 38; Tirmizî, Hudud 3.

Abdulmecid b. Muhammed es-Sebîl, el-Ahkâmu'l-Flkhiyye li-Nakli'l-A'dâi'l-İnsâniyye, 29. 
paylaşan bir bedene benzer" ${ }^{88} \mathrm{Bu}$ hadis-i şerif, mü'minler arasında yardımlaşmanın bedendeki rahatsızlanan organa diğer organların yardım etmelerine benzetilmiștir. Bu açıdan organ naklinin mü'minlerin birbiriyle yardımlaşmaları olarak görülmesi mümkündür. ${ }^{89}$ Başka bir hadisinde Rasûlullah a.s. "Sizden biriniz kendisi için istediğini mümin kardeşi için de istemedikçe iman etmiş olmaz" 90 buyurmuştur. Bu hadis gereği Müslümanın kendisi için istediği şeyi başka bir Müslüman için de istemesi, kendisi için istemediği zor ve kötü durumu Müslüman kardeşi için de istememesi gerekir. ${ }^{91}$

\subsection{Organ Naklinin Îsâr Kapsamında Değerlendirilebileceği Düşüncesi}

Yermük Savaşı'nda sahâbe-i kirâm arasında yaşanan şu hadise bu konuya delil olarak zikredilmiștir: "Yermük Savaşı'nda el-Hâris b. Hişâm, İkrime b. Ebî Cehl ve Ayyâş b. Ebî Rebîa' yaralanmıştı. Savașın akabinde yaralılar arasında su dağıtılırken Hâris'e su getirildiğinde İkrime'nin kendisine (suyu isteyen bir halde) baktığını görünce suyu İkrime'ye götürün dedi. Su İkrime’ye getirildiğinde Ayyâş̧ın kendisine (suyu isteyen bir halde) baktığını görünce suyu Ayyâş'a götürün dedi. Her üçü de su kendisine ulaştığında şehit olmuştu". ${ }^{92}$

Rivâyete göre, bu üç sahâbîden her birinin suyu bir diğerine göndermesi ve neticede her üçünün de mü'min kardeşini kendine tercih etmesi (îsâr), organ bağışı için istidlâl edilen târihî olaylardandır. ${ }^{93}$ Heysemî (ö.807/1405), bu rivâyeti nakleden Habib b. Ebî Sâbit'in Yermük Savaşı'na yetişmediğini ve senette (kendisini veya halini) bilmediği râvilerin olduğunu söylemiștir. ${ }^{94} \mathrm{Bu}$ olayı nakleden rivâyet, Heysemî'ye göre ınkıtâ've cehâletü'l-ayn gerekçelerinden dolayı zayıftır. Bununla birlikte belli şartları hâiz ise zayıf hadislerle amel edilebileceğini düşünen İslam alimleri azımsanmayacak kadar çoktur. ${ }^{95}$ Organ bağışı da faziletli amellerden kabul edilirse, ki Yusuf el-Karadâvî gibi böyle gören kişiler vardır, bu rivâyetle istidlâl yapılabileceği söylenebilir. Kişinin kendisini tehlikeye atarak başkasını kurtarmasının câiz olmadığını düşünen alimler de vardır. ${ }^{96}$ Diğer taraftan İbnü'l-Kayyım el-Cevziyye gibi alimler bunun (kendini tehlikeye atarak başkasını kurtarmanın) câiz olduğunu dile getirmişlerdir.97 Sahâbe-i kiramın başından geçen bu olay, mü'min kardeşin çektiği acının dindirilmesinin sahâbe uygulamasında (sünnetinde) ne denli önemli bir yeri

88 Buhârî, Edeb 27; Müslim, Birr 66.

89 Haylamaz, Íslam Hukukuna Göre Organ ve Doku Nakli, 62; Fikret Karaman, "Organ Nakli ve Dini Boyutu Üzerine Bir Değerlendirme”, Mesned İlahiyat Araştırmaları Dergisi 10/1 (2019), 24.

90 Buhârî, İman 7; Müslim, İman 71, 72.

91 Özdemir, İslam Hukukuna Göre Beden Üzerinde Tasarruf ve Organ Nakli, 129-130.

92 Ebü'l-Kâsım Süleyman b. Ahmed Taberânî, el-Mu'cemü'l-Kebîr, thk. Hamdi b. Abdilmecîd (Musul: Mektebetü'l-'Ulûm ve'l-Hikem, 1983), c. 3, 259, 3342.Hadis.

93 Abdulmecid b. Muhammed es-Sebîl, el-Ahkâmu'l-Fıkhiyye li-Nakli'l-A'dâi'l-İnsâniyye, 29.

94 Ebu'l-Hasen Nureddin Ali b. Ebî Bekr Heysemî, Mecmeu'z-Zevâid ve Menbeu'l-Fevâid, ed. Hüsameddin el-Kudsî (Kahire: Mektebetü'l-Kudsî, 1994), c. 6, 213, 10371.Hadis.

95 Muhammed Abdülhay el-Leknevî, el-Ecvibetü'l-Fâdıla Li'l-Esileti'l-Așarati'l-Kâmile (Kâhire: Mektebetü'l-Matbûâtü'l-İslâmiyye, 1984), 35-65.

96 Abdulmecid b. Muhammed es-Sebîl, el-Ahkâmu'l-Fıkhiyye li-Nakli'l-A'dâi'l-İnsâniyye, 29.

97 Muhammed b. Ebî Bekr İbn Kayyım el-Cevziyye, Zâdü'l-Meâd fî Hedyi Hayri'l-İbâd (Beyrut: Müessesetu'r-Risâle, 1994), c. 3, 442. 
olduğunu gösterir. Bu olayın organ bağışı yapmanın cevazına sarahaten işaret etmediği ancak organ bağışının İslam'da teşvik edilen îsârın genel kapsamına gireceği söylenebilir.

\subsection{Organ Naklinin Belli Şartlarla Câiz Olması}

İnsanın yaşamını devam ettirebilmek için önce kendi nefsinden, sonra ailesinden başlaması gerektiği gibi sağlık bakımından da önce kendi canını öncelemesi gerekir. Hz. Peygamber bir hadisinde: "Önce kendinden başla, kendi nefsine tasaddukta bulun (harca). Bir şey artarsa ailene tasadduk et. Ailenden bir şey artarsa akrabalarına tasadduk et. Akrabalarından da bir şeyler artarsa yakınlık derecesine göre tasadduk et"98 buyurur. Bu nedenle organ bağıșının câiz olması, kendi canını heder edecek bir bağış olmaması şartına bağlıdır. ${ }^{99}$

"Zarar vermek yoktur. Zarara zararla karşılık vermek de yoktur"100 ve “...Her müslümanın, diğer müslümana ırzı, malı ve kanı haramdır..."101 gibi hadis-i şeriflerden istinbât edilen " "الضرر يزال "Zarar giderilir (ortadan kaldırılması "الضرر لا يزال gerekir)" genel kâidesi ve bu kâidenin mutlaklı̆̆gnı takyîd eden "بالضرر, "Zarar bir başka zarar ile ortadan kaldırılamaz" fer'î kâidesi102 organ naklinin mutlak olarak câiz olmadığına delil getirilmiştir. ${ }^{103}$ Organ naklinin cevazına delil getirilen "Zarar giderilir" kâidesinin kapsamına giren meselelerden bir örnek vererek meseleyi somutlaştırabiliriz: "Haram olan bir şeyi yemediğinde ölecek olan muzdar kişi, başka bir muzdar kişinin yiyeceğini yemesi mubah değildir". ${ }^{104}$ Dolayısıyla organ yetmezliği veya iflası gibi sebeplerle yaşam standardını kaybeden hatta ölme tehlikesi olan insanların zararı organ nakli ile ortadan kaldırılabilir ancak organı nakledilecek kișinin zararına rağmen yapılamaz. Zarar, ya hiç zarara yol açmadan ya da daha az/hafif bir zararla kaldırılabilir. ${ }^{105}$ Netice itibariyle bir zarar, başka bir zarara yol açarak giderilemez; vücuttaki tek azaların, insanın vücudunda dışarıdan görünen el, ayak gibi azaların, organdan iki tane olmasına rağmen biri sağlıklı olmayan azaların nakli caiz görülmemiştir. ${ }^{106}$ Aynı şekilde insanın hayattayken kalp ve/veya karaciğeri (nin tamamı) gibi hayati organlarını bağıșlaması intihâr kabilinden değerlendirilmiş ${ }^{107}$ ve "zararın başka bir zararla giderilemeyeceği"

\footnotetext{
98 Müslim, Zekat 41; Ebû Abdirrahmân Ahmed b. Şuayb Nesâî, es-Sünen (el-Müctebâ), thk. Abdülfettâh Ebû Gudde (Halep: Mektebü'l-İslamiyye, 1986), Zekat 60.

99 Arif Ali Arif el-Karadâğî, Kadâyâ Fıkhiyye fî Nakli'l-A'dâi'l-Beșeriyye, 96.

100 Ebû Abdillâh Mâlik b. Enes, el-Muvatta, thk. Muhammed Fuâd Abdülbâkî (Beyrut: Müessesetü Zâyid b. Sultân, 1985), Akdiye 2758/600; İbn Mâce, Ahkâm 17.

101 Müslim, el-Bir ve's-Sıla ve'l-Âdâb 32; İbn Mâce, Fiten 2.

102 Mâzin Misbâh Sabâh, "Kâidetü ed-Darar Yüzâlü - Hücciyyetühâ ve Davâbituhâ", Mecelletü'l-Adl 67 (ts.), 210-212.

103 Karadâvî, Fetevâ-i Muâsıra, c. 2, 533.

104 Abdülkerim Zeydân, el-Vecîz fí Șerhi'l-Kavâidi'l-Fıkhiyye (Beyrut: Müessesetu'r-Risâle, 2009), 88.

105 Zeydân, el-Vecîz fî Şerhi'l-Kavâidi'l-Fılkhiyye, 88.

106 Karadâvî, Fetevấ-i Muâsıra, c. 2, 533.

107 Abdulmecid b. Muhammed es-Sebîl, el-Ahkâmu'l-Fıkhiyye li-Nakli'l-A'dâi'l-İnsâniyye, 44.
} 
kâidesinden hareketle câiz görülmemiştir ${ }^{108}$. İntihârın haramlığı ise Kur'an ${ }^{109}$ ve (birazdan zikredileceği üzere) Sünnet nasslarıyla sabittir. Organ bağışı doğrudan intihâr kabul edilemese de canın korunması zarûrât-ı diniyyedendir (dinin mutlaka korunmasını emrettiği beş şeyden biridir). Yani insanın ilk önce kendi canını kurtarması, hayatını tehlikeye atacak davranışlardan kaçınması gerekir. $\mathrm{Bu}$ nedenle insanın canını korumak için yaptığı nefs-i müdâfaa esnasında öldürülmesine şehitlik sevabı verilmiştir: "Her kim malını korumak için ölürse şehittir. Yine her kim âilesinin ırzını veya kendi canını yahut da dinini korumak için ölürse şehittir".110

İntihârın haram olduğunu gösteren bazı hadis-i şerifler şunlardır:

"Kendisini boğarak öldüren cehennemde kendini boğarak öldürme azabına düçar olur. Kendisini kesici bir aletle yaralayarak öldüren cehennemde kendini kesici bir aletle öldürme azabına düçar olur". ${ }^{111}$

"Her kim kendini bir demir parçasıyla öldürürse, cehennem ateşi içerisinde sürekli olarak demiri karnına sokup duracaktır. Her kim kendisini zehir içerek öldürürse, cehennem ateşi içerisinde elindeki zehiri sürekli olarak içer durur. Kim kendisini dağdan aşağı atarak öldürürse o cehennem ateşi içerisinde sürekli olarak yuvarlanip durur".112

“S̈üphesiz ki bu insan vücudu Allah'ın yapısıdır. Allah'ın yapısı olan bu vücudu helak eden mel'undur". ${ }^{113}$ Zemahșerî'nin (ö.538/1144) Keşşâftefsirinde geçen bu hadisi tahrîc eden Zeylaî (ö.762/1360) hadise "son derece garîb” (غَرِيب جدا yani sadece Zemahşerî̀nin Keşşâfın'da geçecek şekilde ferd bir hadis) demiştir. ${ }^{114} \mathrm{Bu}$ hadis, insanın saygın bir varlık olduğunu, öldürülmesinin de intihâr etmesinin de haram olduğunu gösteren delillerdendir. ${ }^{115}$ Organ nakline cevaz verenler de organ bağışının intihâr gibi hayatı sonlandıracak bir bağış olamayacağını düşünmektedirler. Hasan Ali eş-Şâzelî, intihârın haramlığıyla ilgili bu hadislerle istidlâl ederek organ bağışının kişinin hayatına zarar vereceği kanaatıyla câiz olmadığını düşünmektedir. ${ }^{116}$

\section{6. Ölüm Cezâsı Verilen İnsanların Organlarının Nakli Meselesi}

Hanefî, Mâlikî ve Zâhirîlere göre ölüm cezası verilenlerin kanı masundur (korunmuştur), izinleri olmaksızın organlarından yararlanmak hiçbir surette câiz olmaz; Şâfiî ve Hanbelîlere göre ise bu câizdir. ${ }^{117}$ Abdülaziz b. Bâz (19121999), Hz. Peygamber'den nakledilen “ Allah'tan başka ilah olmadığına ve benim

\footnotetext{
108 Abdulmecid b. Muhammed es-Sebîl, el-Ahkâmu'l-Fıkhiyye li-Nakli'l-A'dâi'l-İnsâniyye, 47-48.

109 Bakara 2/195; Nisa 4/29.

110 Ebû Dâvûd, Sünne 32; Tirmizî, Diyât 22.

111 Buhârî, Cenâiz 84; Ahmed b. Hanbel, el-Müsned, c. 15, 380-381, 9618.Hadis.

112 Müslim, İman 175; Tirmizî, Tıb 7; Buhârî, Tıb 56.

113 Ebü'l-Kāsım Mahmûd b. Ömer Zemahşerî, el-Keşşâf an Hakâiki Gavâmidi't-Tenzîl (Beyrut: Dâru'lKitâbi'l-Arabî, ts.), c. 1, 551.

114 Cemâlüddin Ebû Muhammed Abdullah b. Yusuf Zeylaî, Tahrîcü'l-Ehâdîsi ve'l-Âsâri'l-Vâkıa fî Tefsîri'l-Keşşâf li'z-Zemahşerî, ed. Abdullah b. Abdurrahman es-Sa'd (Riyad: Dâru İbn Hüzeyme, 1993), c. 1, 346, 355. Hadis.

115 Hasan Ali eș-Şâzelî, Hükmü Nakli A'dâi'l-İnsân fî Flkhı'l-İslâmi, 22.

116 Hasan Ali eş-Şâzelî, Hükmü Nakli A'dâi'l-İnsân fî Fıkhı'l-İslâmi, 143.

117 Haylamaz, İslam Hukukuna Göre Organ ve Doku Nakli, 129-130.
} 
Allah'ın rasûlü olduğuma şahitlik yapan hiçbir Müslümanın kanını dökmek helal değildir. Şu üç kişi bundan hariçtir: Maktûle karşı kısasen öldürülmesi gereken kâtil, evli zinakar ve Islam'dan çıkıp Müslüman cemaati terk eden kişi"118 hadis-i şerifiyle istidlâl ederek, kanları koruma altında (معصوم الدم) olmayan kişilerin zaruret durumunda organlarının naklinin câiz olacağını dile getirir. ${ }^{119}$ Yine aynı hadise dayanılarak kâfir, mürted ve zina eden muhsan (evli) kișiye organ naklinin câiz olmadığı, organ naklinin ancak İslam'a uygun bir hayat yaşayan Müslümana yapılabileceği dile getirilmiştir. ${ }^{120} \mathrm{Bu}$ çıkarıma "madem kanı heder olacak, en azından organı başkasına nakledilerek bir faydası olsun" bakış açısıyla ulaşıldığı anlaşılmaktadır. İnsanın kendi rızası veya velisinin rızası olmadan yapılacak bu müdahalenin doğru olmayacağı kanaatindeyiz. Zira bu kişiler yaptıkları suçun cezasını zaten çekmişlerdir. Ayrıca böyle bir muameleye uğratılmaları - ta'zîr cezası kapsamında değerlendirilip değerlendirilemeyeceği ayrı bir araştırma konusudur - insan onurunu zedeleyici bir durumdur. Aynı durum gereği olsa gerek ki Yusuf el-Karadâvî "Deli ve çocuk kendi organlarını bağışlayamayacağı gibi velisinin de - nasıl ki onların mallarını tasadduk etme salâhiyeti yoksa - organlarını bağışlama salâhiyetleri yoktur" demektedir. ${ }^{121}$

\subsection{Donörün Talebi Olmaksızın Organ Nakledilen Kişinin Gönüllü Olarak Ücret Vermesi Meselesi}

"Kendisine organ nakli yapılan kişi daha önce şart koşma veya antlaşma söz konusu olmaksızın kendisine organı bağışlayan donöre hibe, hediye ya da yardım kabilinden mal veya para verebilir mi?" sorusuna en sarih bir şekilde delâlet eden ${ }^{122}$ hadis-i șerifler şunlardır:

"Size kim bir iyilik yaparsa siz de ona iyilikle karşıllı verin. Kim iyiliğin karşılığında verecek bir şey bulamazsa iyiliği yapana dua edin, karşılığını verdiğinizi göreceksiniz".123

"Kime bir iyilik yapılmışsa ona iyilikle karşılık versin. Kim de iyiliğe karşılık vermeye gücü yetmezse o iyiliği ansın. Zira o iyiliği anmak (yad etmek) teşekkür etmektir...".124

Yusuf el-Karadâvî de Rasûlullah'tan a.s. gelen şu hadis-i şerifle cevap vermiştir: "Sizin en hayırlınız borcunu en güzel şekilde ödeyendir"125.126 0, hadis-i şerifin umûmundan çlkarımda bulunmuştur. Bu hadis-i şerifin söylenmesine sebep olan borç ödemesiyle ilgili husûsî olay şöyledir: "Rasûlullah'ın a.s. (bedevî) bir kişiye belli yaşa gelmiş bir deve borcu vardı. O kişi, alacağını istemek için

118 Buhârî, Diyât 6; Müslim, Kasâme 25, 26; Ebû Dâvûd, Hudud 1; İbn Mâce, Hudud 1; Tirmizî, Diyât 10.

119 Abdulmecid b. Muhammed es-Sebîl, el-Ahkâmu'l-Flkhiyye li-Nakli'l-A'dâi'l-İnsâniyye, 44.

120 Abdulmecid b. Muhammed es-Sebîl, el-Ahkâmu'l-Fı khiyye li-Nakli'l-A'dâi'l-İnsâniyye, 46.

121 Karadâvî, Fetevâ-i Muâsıra, c. 2, 533.

122 Arif Ali Arif el-Karadâğ̂̀, Kadâyâ Fıkhiyye fî Nakli'l-A'dâi'l-Beșeriyye, 67-68.

123 Ebû Dâvûd, Zekât 39; Ahmed b. Hanbel, el-Müsned, c. 9, 266, 5365.Hadis; 10, 33, 5743.Hadis; 10, 267, 6106.Hadis; Nesâî, Zekât 72.

124 Ahmed b. Hanbel, el-Müsned, c. 41, 142, 24593.Hadis.

125 Buhârî, Vekâle 5; İstikrâz 7; Nesâî, Buyû' 64, 103.

126 Karadâvî, Fetevâ-i Muâsıra, c. 2, 534. 
Rasûlullah'ın yanına geldi ve alacağını (başka rivâyetlerde biraz da sert ve kaba bir üslupla127) istedi. Rasûlullah a.s. ödenmesi gereken yaşta bir deve bulup vermelerini emretti. Sahâbe-i kirâm o yaşta bir deve bulamadılar ama o kişinin devesinden daha iyi bir deve buldular. Hz. Peygamber o buldukları iyi deveyi vermelerini emretti. Bunu gören kişi "Bana olan vereceğini tastamam ödeyerek borcuna vefâlı olduğun için Allah da sana mükâfâtını tastamam versin" diyerek duâ etti. Bunun üzerine Rasûlullah a.s. "Sizin en hayırlınız borcunu en güzel bir şekilde ödeyendir" buyurdu". ${ }^{28}$ Bu hadis-i şerifte anlatılan hâdise özel bir olay olmasına rağmen "sebebin husûsî olması hükmün umûmî olmasına engel değildir" kâidesi gereği, genel çıkarımlarda bulunmanın bir sakıncası yoktur. Dolayısıyla organ nakli gerçekleşen kişinin imkanı ölçüsünde, organını bağışlayarak donör olan kişiyi bir miktar mal veya para ile sevindirmesi güzel bir davranış olacaktır.

\section{8. Ölümünden Sonra Organının Bağışlanmasını Vasiyet Etmesi Meselesi}

Yusuf el-Karadâvî bu meseleye dair merfû bir hadisle istidlâl etmemekte ancak Hz. Ömer'in r.a. başından geçen bir hadisede söylediği şu mevkuf hadisle istidlâl etmektedir: "Dahhâk b. Halîfe, Üreyd denilen nehirden bir su kanalı açtı ve bunu Muhammed b. Mesleme'nin arâzisinden geçirmek istedi. Muhammed bunu kabul etmeyince Dahhâk ona "Buna neden mani oluyorsun?! Bu senin de menfaatine olan bir şey. Bu kanaldan önce de sonra da (dilediğin zaman) su kullanabilirsin. Ve bu sana zarar verecek bir șey de değil” dedi. Muhammed kabul etmeyince Dahhâk meseleyi Ömer b. Hattab'a anlattı. Hz. Ömer Muhammed b. Mesleme'yi çağırıp ona Dahhâk'ın suyu arâzîsinden geçirmesine izin vermesini emretti. Muhammed hayır deyince Hz. Ömer 'Kardeșin için faydalı olan bir şeye neden mani oluyorsun? Ki teklif edilen şey senin için de faydall, bu kanaldan önce de sonra da (dilediğin zaman) su kullanabilirsin ve ayrıca sana zararı da yok.' dedi. Muhammed hayır deyince Hz. Ömer 'Vallahi Dahhâk o kanalı arâzînin ortasından geçirecek' dedi ve Hz. Ömer Dahhâk'a kanalı arâzîden geçirmesini emretti o da kanalı Muhammed'in arâzîsinden geçirdi”. ${ }^{129}$ Bu hâdisede Hz. Ömer r.a., ${ }^{130}$ sosyal ilişkilerde temel kural olacak şu cümleyi söylüyor: "Kardeşin için faydalı olan bir şeye neden mani oluyorsun? Ki teklif edilen şey senin için de faydalı ve ayrıca sana zararı da yok!”. Yani bir Müslümanın, kendisi için zararlı değilse ve mümin kardeşine de faydalı olacaksa bir şeye karşı çıkması doğru olmaz. Buradan hareketle Yusuf el-Karadâvî, (insanın vefatından sonra organlarının zaten toprak olacağını, bağışlanan organı sebebiyle kendisine bir zarar gelmeyeceğini, organın nakledildiği İslam'da veya insanlıkta kardeşi olan kişiye de faydalı

127 Buhârî, Vekâlet 6.

128 Buhârî, Vekâle 5.

129 Mâlik b. Enes, Akdiye 836; Ebûbekir Ahmed b. Hüseyin b. Ali Beyhakî, Sünenül'l-kübrâ (Beyrut: Dâru'l-ma'rife, 1346), c. 5, 23, 8854.Hadis.

130 Hz. Ömer'in r.a. daha önce Dahhâk'ın aynı sözü söylediğini duyup duymadı̆̆ını, yani sözün asıl sahibinin Dahhâk mı yoksa Hz. Ömer mi olduğunu bilmiyoruz ama bu kadâî (yargıyla ilgili) meselede son sözü o söylediği için prensip olarak bu sözü doğru kabul ettiğini anlıyoruz. Bunu Rasûlullah'ın a.s. sahâbî uygulamasını onayladıktan sonra o davranıșın artık sahâbî tercihi değil sünnet olmasına benzetebiliriz. 
olacağını dile getirerek) kişinin hayattayken kendine zarar verme ihtimâline rağmen organını bağışlaması câiz ise ölümünden sonra bağışlanması için vasiyet etmesi evlâ olarak câizdir demiștir.

Yusuf el-Karadâvî, Hz. Peygamberin "Ölmüş insanın kemiğinin kırılmasl, dirinin kemiğinin kırılması gibi günahtır"131 hadis-i şerifiyle istidlâl ederek, ölen insanın organının nakli esnasında ona eziyet verileceğini ve bu durumun insanın saygınlığını çiğnemek olacağını düşünerek organ bağışını vasiyet etmeye itiraz edenler olabileceğini dile getirir ve bu muhtemel itiraza da cevap verir. Organ nakli esnasında ölüye de canlı kişiden organ nakledilirken gösterildiği gibi hassâsiyet gösterildiğini (en azından gösterilmesi gerektiğini) ${ }^{132}$ ve hadis-i şerifte dile getirilen "kemiğin kırılması" hususunun müsle ${ }^{133}$ yapmanın nehyi kapsamında olduğunu dile getirir. Ancak Yusuf el-Karadâvînin ölünün kemiğinin kırılmasını müsle olarak anlaması yanlış bir anlamadır. Daha önce de ifade ettiğimiz gibi Hz. Peygamber'in ölünün kemiğinin kırılmasını yasakladığı sözünü, kabrin içinden çıkan kemiklerin ölüye saygı gereği kırılmayıp, mezarın kenarına toplanmasını emrettiğinde söylemiştir.

Ayrıca Yusuf el-Karadâvî, organ naklinin selef-i sâlihîn tarafından yapılmamasının onların zamanında bunun mümkün olmamasından kaynaklandığını dile getirir ve "zamanın (ve mekanın, şartların) değişmesiyle hükümlerin değişmesinin inkar olunamayacağı" kuralını hatırlatır. ${ }^{134}$

\subsection{Velinin Vefat Eden Yakınının Organlarını Bağışlaması Meselesi}

Yusuf el-Karadâvî, "Nasıl ki kişi vefat ettiğinde malı vârislerine intikal ederse meyyitin vücudu da artık kendi mülkü olmaktan çıkar, yakınlarının tasarrufuna girer" der. Ona göre kişi öldürüldüğünde nasıl ki yakınlarına kısas veya affetme ${ }^{135}$ veya diyet üzere anlaşma ${ }^{136}$ hakkı verilmişse, meyyitin bedeni de yakınlarının tasarrufuna bırakıldığı kabul edildiğinde, meyyite zararı dokunmaması ve bașkasına faydası olması șartıyla, organlarını bağışlayabilecekleri söylenebilir. ${ }^{137}$ Hatta organ sahibinin böyle bir şeye niyeti olmasa da hasta olup ızdırap çekenlere fayda sağladıkları için meyyitin velilerinin bundan sevap kazanacakları da umulur. Nitekim kişi hayatta iken kendi izni olmaksızın yetiștirdiği ürünlerinden insan, hayvan yediği zaman kendisi için sadaka oluyorsa, meyyitin haberi olmadan onun adına yapılan bu iyilikten kendisine sadaka sevabı yazılacaktır. Yusuf el-Karadâvî bu meseleyi ispat ederken şu hadis-i șeriflerle istidlâl etmiștir:

131 Ebû Dâvûd, Cenâiz 67; İbn Mâce, Cenâiz 63.

132 Karadâvî, Fetevấ-i Muâsıra, c. 2, 535.

133 İnsan olsun hayvan olsun öldürülen (maktulün) varlığın burnunu, kulağını ve diğer azalarını kesmek sûretiyle o varlığı çirkin göstermeye ve bu yolla yakınlarının moralini bozmayı amaçlayan uygulamaya müsle diyebiliriz. Hz. Peygamber hem insana hem de hayvana müsle yapılmasını yasaklamıștır.

134 Karadâvî, Fetevâ-i Muâsıra, c. 2, 536.

135 İsrâ $17 / 33$.

136 Bakara 2/178.

137 Karadâvî, Fetevâ-i Muâsıra, c. 2, 536. 
"Müslüman bir kişi bir ağaç diker veya ekin eker de ondan insan, hayvan veya kuş yerse, bu yenen şey o kimseye sadaka olarak yazılır".138

"Yorgunluk, sürekli hastalık, tasa, keder, sıkıntı ve gamdan, ayağına batan dikene varıncaya kadar müslümanın bașına gelen her șeyi, Allah c.c. onun hatalarını bağışlamaya vesile kılar" ${ }^{139}$

Yusuf el-Karadâvî birinci hadiste, Müslüman bir kișinin vasiyeti olmaksızın bağışlanan organlarından elde edeceği sevabı, kendisinin haberi olmadan diktiği ağacın meyvesinden yenilmesiyle elde edeceği sadaka sevabına kıyaslamıştır. İkinci hadis-i şerifi, hayatı ve öldükten sonrasını kapsayacak şekilde âmm bir lafız olarak yorumlamış ve "Nasıl ki Müslüman hayattayken başına gelen hastalık, gam, keder, eziyet hatta batan bir dikenden dolayı çektiği ızdırap sebebiyle günahları affediliyorsa veya kendisine hasene (sevap) yazılıyorsa ${ }^{140}$, vefat ettikten sonra vücudundan alınan organlar sebebiyle çekeceği eziyet onun için günahlarına keffâret veya sevap olarak defterine yazılacaktır" diyerek yorumlamıștır.

Yusuf el-Karadâvî'nin birinci hadise yaptığı yoruma iki şekilde bakılabilir: 1- Yapılan yorum, hadisin mahiyet ve gâyesine uzak, merdûd bir yorum değildir. İnsanın yetiştirdiği mahsullerden haberi olmadan yenenler nasıl kendisi için sadaka oluyorsa vasiyeti/haberi olmadan bağışlanan organları da kendisi için sadaka olur. 2- Akıl ve irâde sahibi, kullukla mes'ul, eşref-i mahluk olarak yaratılan mükerrem insan vücudu ile bu özelliklere sahip olmayan ağaçların meyvelerinin kıyaslanması nedeniyle kıyas maa'l-fârık denilebilir. Çünkü insan canlı haliyle de ölü haliyle de mükerremdir; bitkiler ise böyle değildir. Eşref-i mahluk insanın organlarının bağışlanmasıyla, ağaçların meyvelerinin yenilmesiyle elde edilecek sadaka aynı olmasa gerektir.

Yusuf el-Karadâvînnin ikinci hadise getirdiği yoruma zorlama denilebilir. Zira "canlı iken çektiği ızdırap" ile "vefat ettikten sonra organı nakledilirken eziyet çekeceği” kabul edilerek kıyâs edilmiştir. Halbuki kiși öldükten sonra, hislerini kaybettiği için organ nakli sebebiyle acı ve ızdırap çekmez. Daha önce üzerinde durulan "Ölmüş insanın kemiğinin kırılması, dirinin kemiğinin kırılması gibi günahtır" hadisinin, insanın şahsı manevisine saygısızlık olacağı için mezarda bulunan kemiklerin kırılmayıp kenara toplanması gerektiğini nakletmiştik. Dolayısıyla, kişinin vasiyeti olmaksızın velilerinin yapacağı organ bağışından sevap elde edebileceği fetvâsını birinci hadis destekleyebilir; ikinci hadisle yapılan istidlâlin ise doğru bir istidlâl olmadığı kanaati bizde hasıl olmuştur. Netice olarak Yusuf el-Karadâvî, meyyitin yakınlarının, meyyit adına sadaka vermek niyetiyle organlarını bağıșlamalarına dini bir engel olmadığını düşünmektedir. Organ nakli yapılan kişi hayatta kaldığı ve nakledilen bu organdan yararlandığı müddetçe donör olan bu kişiye sadaka yazılmaya devam edecektir. Yine aynı konuyla bağlantılı olarak yeni doğmuş ve bazı rahatsızlıkları sebebiyle yaşama imkanı çok zayıf olan bebeklerin organlarının anne babaları tarafından bağışlanmasının da câiz olacağı dile getirilmiştir. Eğer kişi hayatında

138 Buhârî, Müzâraa 1; Müslim, Müsâkât 7-12.

139 Buhârî, Merdâ 1, 3; Müslim, Bir 49, 50, 51.

140 Müslim, Bir 51. 
iken organlarının bağışlanmaması için vasiyette bulunursa, yakınlarının bu vasiyete göre hareket etmesi gerekir. ${ }^{141}$

\subsection{Devlet'in Kimsesiz Vatandaşların Organlarını Nakle İzin Vermesi Meselesi}

Hz. Peygamber bir hadisinde "Sultan (devlet başkanı), velisi olmayanın velisidir". ${ }^{142} \mathrm{Bu}$ hadis-i şerifin de delâlet ettiği üzere, vefat eden kişinin yakınlarının (velileri) nasıl ki ölen kişinin organlarını bağışlaması câizse, devlet yetkililerinin de zaruret veya zarûrete yakın ihtiyaç durumlarında kimsesi olmayan kişilerin organlarının nakline izin vermelerinde bir mahzur olmadığı söylenebilir. ${ }^{143} \mathrm{Bu}$ hadis-i şerifle istidlâl edilerek, devlet başkanının veya yetki verdiği kurumların hasta olan vatandaşının hayatını devam ettirmek için maslahat gereği böyle bir karar alabileceğini anlıyoruz. Konuyla alakalı bu hadisten istidlâl edilmesinin yanlış bir yorum olmadığını söyleyebiliriz.

\subsection{Gayr-i Müslimin Organının Müslümana Nakli Meselesi}

Gayr-i müslimin vücudu ve dolayısıyla organları necis değildir. Eğer öyle olsaydı Hz. Peygamber onları mescidde ağırlamazdı: "Sekîf heyeti Medîne’ye geldiğinde Hz. Peygamber onları mescidde ağırladı .....144

Gayr-i müslimin organının Müslümanın vücuduna naklinde dinen bir sakınca yoktur. Zira organın Müslümanı kafiri olmaz. Organ nakledildikten sonra artık Müslümanın vücudundan bir parça olmuştur. Hatta organ, kafir bir kişide iken de Müslümandır, Allah'ı kendi lisanı ile tesbih etmektedir. İman ve küfür ile nitelenen kalp, tıp ilminin konusu olan, kanı pompalayan kalp değildir. Bu vasıflarla kastedilen kalp, inanan, inkar eden, akleden, kavrayan ${ }^{145}$ rûh-i ma'nevî olan kalptir. "Müşrikler necistir (pistir)"146 âyetiyle kastedilen de bedenî kirlilik değil, manevî kirliliktir. ${ }^{147}$

İnsan öldügünde vücudunun artık necis olduğunu, ibadetlerle iştigal edecek insana necis varlıktan organın naklinin câiz olmayacağını kabul eden alimlerin kanaatlerinin doğru olmadığı dile getirilmiştir. Bu nedenle "İnsanın ölüsü, diğer ölülerin aksine temizdir" denilmiștir. ${ }^{148}$ Nitekim Hz. Peygamber “...Mü'min necis olmaz"149 buyurmuştur. İbn Abbâs r.a. ise şöyle der: "Müslümanın dirisi de ölüsü de necis değildir"150. Saîd b. Zeyd'in cenazesini yıkayan Sa'd b. Ebî Vakkâs da "Ĕger cenâze necis olsaydı ona dokunmazdım"151 demiştir. Dolayısıyla beyin ölümü

141 Karadâvî, Fetevâ-i Muâsıra, c. 2, 537.

142 Ebû Dâvûd, Nikah 20; Tirmizî, Nikah 14.

143 Karadâvî, Fetevâ-i Muâsıra, c. 2, 537; Abdulmecid b. Muhammed es-Sebîl, el-Ahkâmu'l-Fıkhiyye liNakli'l-A'dâi'l-İnsâniyye, 59.

144 Ahmed b. Hanbel, el-Müsned, c. 29, 438, 17913.Hadis.

145 Hac 22/46; A'râf 7/179.

146 Tevbe $9 / 28$.

147 Karadâvî, Fetevâ-i Muâsıra, c. 2, 538; Abdulmecid b. Muhammed es-Sebîl, el-Ahkâmu'l-Fıkhiyye liNakli'l-A'dâi'l-İnsâniyye, 23.

148 Arif Ali Arif el-Karadâğî, Kadâyâ Fıkhiyye fî Nakli'l-A'dâi'l-Beșeriyye, 132.

149 Buhârî, Güsul 24; Müslim, Hayız 371.

150 Buhârî, Cenâiz 8.

151 Buhârî, Cenâiz 8. 
gerçekleșmiş Müslümanın cenazesinin necis olduğunu düşünmek doğru değildir. ${ }^{152}$

\subsection{Necis Bir Hayvanın Organının Müslümana Nakli Meselesi}

Yusuf el-Karadâvîye göre zarûret olmadığı müddetçe, necis bir hayvanın organını insana nakletmemek gerekir. Zarûret sebebiyle verilecek cevâzın miktarı ve sınırı zaruretin durumuna, miktarına göre değişir. Dolayısıyla nasıl ki muzdar olan (açlık veya susuzluk tehlikesiyle karşılaşan) kişinin açlıktan ölmeyecek kadar domuz eti yemesi, susuzluktan ölmeyecek kadar içki içmesi caizse, bu sınırı aşıp haram olan domuz etinden tıka basa yiyemezse, şaraptan zaruret miktarından fazlasını içemezse, necis olan hayvandan yapılacak organ naklinde de gerekli kılan miktarı aşmamak gerekir. Cevâz verilebilmesi için bir diğer şart, güvenilir tabiplerin bunun faydalı olacağına dair görüş beyan etmesidir.

Domuzun, etinin yenilmesi haram kılınmıştır ancak organının nakli bu haram kapsamında değildir. Buradaki mesele, necis olan bir hayvandan yararlanmadır. Rasûlullah a.s., necis olmasına rağmen leşin derisinden yararlanmaya cevaz vermiştir. Hadis-i şerif şöyledir: "Hz. Peygamber, eşi Meymûne'nin azatlı kölesine zekat mallarından verilen koyunun leşini görmüştü. Bunun üzerine Hz. Peygamber 'Onun derisinden yararlansaydınız ya!' buyurmuştu. Onlar da 'Ya Rasûlullah o bir leş (ondan yararlanmak câiz midir)!' diye şaşkınlıklarını beyan edince, Hazret-i Peygamber 'Onun yenilmesi haram kılındı!' buyurdu". ${ }^{153}$ Yusuf el-Karadâvî, yenmesi haram olan domuzun organından nakil yoluyla yararlanmayı, yenmesi haram olan leşin derisinden yararlanmaya kıyas etmiștir. 0 necis hayvandan insana organ naklinin cevâzının mutlak olmadığını, elden geldiğince uzak kalınması gerektiğini, karar verme aşamasında ehil ve güvenilir doktorların bu naklin faydalı olacağına dair kanaatinin olması gerektiğini ifade etmiştir. 0, "Zira dinde haram olan, domuzun etini vücudun dışında taşımaktır. Domuzun organı naklediltikten sonra, hayvanın organının insan vücudunun içinde olmasının dinen mahzuru yoktur" der. ${ }^{154}$

\subsection{Nakledilen Organlar Haşir Esnasında Bağışlayana Mı Nakledilene Mi Ait Olarak Yaratılacak Meselesi}

İnsanlar nakledilecek organların kıyamet gününde kime ait olacağını merak etmektedirler. Zira Allah c.c. Kur'an-ı Kerîm'de “O gün onların ağızlarını mühürleriz; yapmış olduklarını elleri bize anlatır, ayakları da tanıklık eder"155 buyurmaktadır. Bu konuda şu hadis-i şerif bizlere ışık tutmaktadır "... Sonra Allah gökten bir (hayat) suyu indirir ve bu sayede ölüler, bitkinin yerden bitişi gibi (kabirlerinden) çıkarlar. Insan cesedi bütünüyle çürüyüp yok olur, ancak acbü'zzeneb müstesna, insanlar bundan yaratılır"156. Hadis-i şerifte görüldügü üzere

\footnotetext{
152 Abdulmecid b. Muhammed es-Sebîl, el-Ahkâmu'l-Flkhiyye li-Nakli'l-A'dâi'l-İnsâniyye, 23.

153 Buhârî, Zekât 61; Müslim, Hayz 101.

154 Karadâvî, Fetevâ-i Muâsıra, c. 2, 539.

155 Yasin 36/65.

156 Buhârî, Tefsir, Nebe 78/1.
} 
insanların organları hatta kemikleri çürüyecek sadece "acbü'z-zeneb" denilen insanın ilk yaratılışında ve öldükten sonraki dirilişinde bedenin özünü oluşturduğu kabul edilen küçük bir madde ${ }^{157}$ çürümeyecek ve bu parçadan yaratılacaktır. Ayet-i kerimeden insanın yaptıklarını organlarının anlatacağını, yaratılışta ruh ile aslî organların esas olduğunu, organlar dağılsa bile Allah'ın bu organları yine aynı şekilde yaratmaya kadir olduğunu ${ }^{158}$, bu yaratılışın ise Allah c.c. için "ol"159 deme kolaylığında insanın acbü'z-zeneb maddesinden olacağını anlamaktayız. Diğer taraftan metafizik meseleler olduğu için somut bir şekilde kavranması mümkün olmamaktadır.

\section{Organ Nakli İçin Beyin Ölümünün Gerçekleşmiş Olmasının Gerekliliği}

Beyin ölümü modern dönem meselelerinden olduğu için doğrudan tıbbın karar vereceği bir durumdur. Bu konuda fetvâ veren alimler "Bir şeyin - ilgili hükmü ortadan kaldıracak hilâfına delil olmadıkça - bekasıyla hükmolunur” ve "Müslümanda asıl olan günahlardan beri olması ve âdil olmasıdır" şeklindeki küllî kâidelerle ve ıstıshâb deliliyle, mes'elesinin hassasiyetinden dolayı ihtiyatı elden bırakmamaya, bıraktırmamaya çalıșmışlardır. Yani kișinin beyin fonksiyonlarında asıl olan çalışması, kişiyi hayata bağlamasıdır. Öldüğüne dair yakîn hasıl olmadıkça acele edilerek organ nakli yapmaya çalışmamak gerekir. Kişinin gerçekten öldüğünün şüphe bırakmayacak şekilde kesinleștirilmesi son derece önemlidir.160 2007 yılında gerçekleștirilen "Güncel Dini Meseleler Toplantısı"nda konu uzman tabipler ve ilahiyatçlar tarafından ele alınmış ve beyin ölümünün hakiki ölüm olduğu, bu durumdaki hastalardan organ nakline izin verilebileceği sonucuna varılmıștır. ${ }^{161}$

Muhammed Ra'fet ölümü üçe ${ }^{162}$ ayırsa da ${ }^{163}$ günümüzde dünya genelinde ölüm ikiye ayrılmaktadır: 1- Somatik Ölüm: Dolaşım ve solunum sistemlerinin yapay destek almaksızın çalışmaması ve santral sinir sistemi fonksiyonlarının durmasıdır. 2- Beyin Ölümü: Kalbin çalışmasına rağmen sistemler arası koordinasyonun giderek bozulması ve tüm vücudun canlı olduğu dönemdeki işlevlerini yürütememesine denir. ${ }^{164}$ 04.01.2014 tarihli yasayla beyin ölümüne,

157 Yusuf Şevki Yavuz, “Acbü'z-Zeneb” (İstanbul: Türkiye Diyanet Vakfı Yay., 1988).

158 Haylamaz, Íslam Hukukuna Göre Organ ve Doku Nakli, 98; Karaman, “Organ Nakli ve Dini Boyutu Üzerine Bir Değerlendirme", 21.

159 Yasin 36/82; Gafir 40/68.

160 Abdulmecid b. Muhammed es-Sebîl, el-Ahkâmu'l-Fıkhiyye li-Nakli'l-A'dâi'l-İnsâniyye, 61-74.

161 Mustafa Ünverdi, "Yeniden Dirilişin Keyfiyeti Bakımından Organ Nakli", Dinbilimleri Akademik Araştırma Dergisi 15/1 (2015), 47.

162 Kalbin durmasıyla gerçekleșen "klinik ölüm” (yatakta ölüm - موت سريري - clinical death), kalbin beş dakikadan daha fazla süre çalışmamasıyla gerçekleşen "beden ölüm”ü الموت الجسدي - Somatic Death) ve beynin fonksiyonlarını kaybettiği “beyin ölümü” (الموت الخلوي - Programmed cell death (Apoptosis)) şeklinde üç merhalesinin olduğunu dile getirir. Birinci ölüm türünün tespitinde alimler arasında ihtilaf yokken beyin ölümünün tespitindeki isâbet hakkında ihtilaf olduğunu söylemiştir.

163 Muhammed Ra'fet Osman, "Naklü ve Zer'ü'l-A'dâ”, 5-6.

164 Dr. Behnan ALPER vd., “Ölüm”, Adli Otopsiler ve Adli Patoloji (Erișim 05 Eylül 2021). 
tıp kurallarına uygun ve kanıta dayalı olarak, biri nörolog veya nöroşirurjiden, biri de anesteziyoloji ve reanimasyon veya yoğun bakım uzmanından oluşan iki hekim oy birliğiyle karar verir. ${ }^{165}$ Bütün bilimsel gelişmelere rağmen ölüm tanısının konmasında kesin bir yargıya ulaşılamadığı dile getirilmektedir ${ }^{166.167}$ Beynin geri dönülemez şekilde öldügünün tespiti konusundaki bu şüpheler nedeniyle alınacak karar son derece önemli olacaktır. Muhammed Ra'fet, hastanın yaşadığının kesin olduğu, beyin ölümünün gerçekleştiğinin ise şüpheli olduğu yargısından dolayı "Yakînî bilgi şüphe ile ortadan kalkmaz" kâidesi ve bu kâideyi oluşturan şu hadislerle istidlâlde bulunmuştur:

"Sizden biri, karnında bir şeyler hisseder ve fiilen bir şeylerin çıkıp çıkmadığı hususunda tereddüd ederse, ses işitmedikçe veya koku duymadıkça mescidden çımasın".168

"Sizden biri namazda üç rekat mı yoksa dört rekat mı kıldığı konusunda şüphe ederse, şüpheyi atsın ve yakîn olan bilgisine göre namazına devam etsin ...".169

$\mathrm{Bu}$ hadislerden istinbât edilerek oluşan "Yakînî bilgi şüphe ile ortadan kalkmaz" kaidesi gereğince, yaşadığı kesin olan ve beyin ölümü gerçekleştiği konusunda kesin tanı konulmamış kişiler hakkında beyin ölümü gerçekleşmiştir kararı almamak gerekir. Zira gerçek anlamda ölmemiş kişiden organı alınarak ölümüne sebep olma ihtimali vardır.

\section{Organ Nakli Konusunda Hadisle İstidlâl Edilmeyen Meseleler}

Organ nakli konusunda hadisleri dikkate alarak sunmaya çalıştığımız bu çalışmada, konuyla ilgili başka meselelerin de olduğunu fark ettirmek için hadisle istidlâl edilmese de tartışılan ve çözüme dair fikir beyan edilen bazı meseleleri kısaca sunmak istedik:

1- "Erkek üreme organı husyelerin (erbezi) nakli" meselesinde hadislerle değil, zarûrât-ı diniyye gibi küllî kaidelerle cevap aranmaya çalışılmıştır. Bu konuda iki farklı kanaat vardır: Husye naklinin câiz olmadığını düşünen birinci görüşe göre, 'Husye kişinin nesline aktardığı kalıtsal özelliklerini, DNA'sını taşımaktadır. Husye nakli gerçekleşirse, bu kalıtsal özellikler nakledilen kişiye ve onun nesline geçeceği için nesillerin karıșması söz konusu olacaktır. Nesebin ve ırzın korunması ise zarûrât-i diniyyeden (dinin mutlaka korunmasını emrettiği beş şeyden) olduğu için husye nakli caiz değildir. ${ }^{170} \mathrm{Bu}$ organların naklinin câiz olduğunu düşünenler ise, bu organların sadece üremeyi temin ve tanzim eden birer âlet olduğunu, üreme âleti olan bir organın bir vücutta değil de başka bir vücutta çalışacağını düşünmektedirler. ${ }^{171}$

165 Selma Bıyıklı Adabaş, "Beyin Ölümüne 4 Yerine 2 Hekim Karar Verecek”, Anadolu Ajansı (04 Ocak 2014).

166 Dr. Behnan ALPER vd., "Ölüm”.

167 (Bununla birlikte, Beyin Cerrahi Uzmanı bir tabiple yaptığım istişarede, bu uzmanların aldıkları ortak kanaatin yanlış olma olasılığının neredeyse imkansız olduğu bilgisi paylașılmıștır.)

168 Müslim, Hayz 99, 98; Buhârî, Vudû 4, 32, Buyû' 5.

169 Müslim, Mesâcid 88; İbn Mâce, İkâmetü's-Salat 132; Ebû Dâvûd, Bâbu Tefrî’i Ebvâbi'r-Rukû' 47, 48.

170 Karadâvî, Fetevâ-i Muâsıra, c. 2, 539.

171 Abdulmecid b. Muhammed es-Sebîl, el-Ahkâmu'l-Fıkhiyye li-Nakli'l-A'dâi'l-İnsâniyye, 51. 
2- Husyenin naklini câiz görmeyenler buna kıyasla, şayet tıbbî anlamda imkan olur da beyin nakli de gerçekleşecek olursa, beyin naklinin câiz olmayacağını dile getirmektedirler. Çünkü bunda da insan irade ve bakış açısının fesadı söz konusu olacaktır. ${ }^{172}$

3- Savaş halinde olmayan gayr-i müslime organ bağışlanabilir. İster askerî olsun isterse fikrî olsun Müslümanlarla savaş halinde olan gayr-i müslime organ bağışı caiz değildir. Organ nakline aynı anda Müslümanın ve gayr-i müslimin ihtiyaç duyduğu durumda ise Müslümanın tercih edilmesi gerekir. Yusuf elKaradâvî'ye göre, bir kişinin organını şahsa bağışlayabildiği gibi ihtiyaç halinde hemen nakledebilmeleri için Organ Nakil Bankaları gibi müesseselere de bağışlayabilir. ${ }^{173}$

\section{Sonuç}

Organ nakliyle alakalı ilmi çalışmalarda hadislerle istidlâlin çokça yapıldığını gördük. Bu da doğaldır zira dinin iki kaynağı Kur'an ve Sünnet'tir. Organ nakli hakkında Kur'an'da veya Sünnet'te doğrudan ve sarahaten nasslar bulunmamaktadır. Ancak İslam alimleri, organ naklini câiz görsün veya görmesin, nassların umumundan fikhu'l-hadis yapmışlardır.

Organ nakli meselesine dini açıdan çözüm aranırken, İslam'ın modern tıbbın verilerini de dikkate aldığını, bununla birlikte yanlış bir sonuca varmamak için işi gayet ciddi tuttuklarını gördük. Bu durum İslam'ın ve Müslüman alimlerin ilme ve modern bilime bigane kalmadığını, bilimin vardığı sonuçlardan yararlandıklarını gördük.

Organ naklinin câiz olmadığını düşünen alimlerin iddialarını destekleyecek ve kuvvetlendirecek ciddi hadis delillerinin olmadığı kanaati bizde hasıl olmuştur. $\mathrm{Bu}$ çalışmada hadislere odaklanmaya çalıştığımız göz ardı edilmemelidir. Organ naklinin câiz olmadığını düşünen alimler âyet-i kerimeler, hadisler, küllî kâideler ve başka delillerle iddiâlarını ispat etmeye çalışmışlardır. Hadisler açısından değerlendirdiğimizde, lafzî ve zâhirî yorumlarla organ naklinin câiz olmadığını kabul ettikleri dikkat çekmektedir.

Organ naklinin câiz olduğu görüşünü benimseyen alimlerin, istidlâl ettikleri hadislerin oran olarak fazla olduğu, hadislere yaptıkları fıkhu'l-hadîsin ve hüküm istinbatlarının daha isâbetli olduğu gözlenmiștir. Hadislerin umûmî yönlerine odaklanılmış, genel küllî kâidelere temas edilmiştir. İslam'ı yaşanılır ve hayatı kolaylaştırır bir anlayışla okumanın ve sorunlara çözüm üretmenin çabası içinde olduklarını söyleyebiliriz. Bu durum, organ naklini câiz görmeyenlerin bağnaz, tutucu, yeni gelişmelere kapalı olduğu anlamına gelmez. Onların organ nakli konusunda toplumda karşılaşılan istismarlar ve kul hakkına tecâvüzler sebebiyle hassas oldukları dikkat çekmektedir. Organ naklinin ister câiz olduğunu düşünsün ister câiz olmadığını düşünsün, bu konunun gerek kanuni gerekse dini şartlarına riâyette son derece hassas olunması gerekir.

Biz bu çalışma vesilesiyle bir kez daha gördük ki, Kur'an-ı Kerîm yanında sünnet verileri hadislerin sağlıkla ilgili bu meselelerde de son derece önemli bir

172 Karadâvî, Fetevâ-i Muâsıra, c. 2, 539-540.

173 Karadâvî, Fetevâ-i Muâsıra, c. 2, 534. 
fonksiyon icrâ etmektedir. Kur'an ile birlikte hadislerden istinbât edilen küllî kâideler ve sınırlı sayıdaki deliller, sınırsız probleme çözüm üretmektedir. Organ nakli konusu modern çağın meselelerindendir ve içtihâdîdir. İçtihâdî meselelerde hiçbir içtihâd bir diğerini nakz etmez. İslam alimleri aynı kaynaktan beslendikleri halde farklı hükümlere varmaktadırlar. $\mathrm{Bu}$ durum, farklı hükümlere ulaşmaya imkan verecek şekilde delillerin farklılığına ve onların ilmî yeterliliklerinin ne kadar güçlü olduğuna delildir. Bunun sebebi kaynakları okuma, anlama, muhâkeme ve istinbât etme melekelerinin farklılığından olabileceği gibi dönemsel şartların sebep olduğu olumsuz örneklerin böyle hükümlere varmalarına da sebep olabilmektedir. Başka bir sebep de, Yusuf elKaradâvî'de görüldügü gibi, maslahat dâiresini gayet geniş tutma veya organ nakline cevaz vermeyenlerde olduğu gibi mefsedeti def' etmenin daha önemli görülmesinden kaynaklanabilmektedir. Sedd-i zerâi' delili işletilirken sadece zarardan korunmak için bir uygulamayı reddetmek elde edilecek maslahattan mahrumiyete de sebep olabilir. Bu dengenin iyi korunması gerekir.

İslam dininin, ister Müslüman olsun ister gayri müslim olsun, insanın dirisine değer verdiği gibi ölüsüne de değer verdiğini gördük. Organların satılmasının insan onuruna aykırı olduğunu gördük. Bedenen acı çekmeyecek ve bir müddet sonra çürüyüp ufalanacak olsa bile şahsı manevisini ve belki de tanıdıklarının gönüllerini inciteceğinden insanın kemiklerinin kırılmasını nehy etmiştir. Ölüm cezasına çarptırılan insanlar bile olsa rızaları olmadan organlarının naklinin insan onurunu zedeleyeceği için karşı çıkıldığını gördük. Diğer taraftan insana verilen değer gereği İslam'ın insanın canını korumak, sağlığını temin etmek, acılarını dindirmek için son derece ilgili olduğunu, insanların acı ve ızdıraplarına bigane kalmadığını gördük.

Finansman / Funding:

This research received no external funding. / Bu araştırma herhangi bir diş fon almamiştır.

Çıkar Çatışması / Conflicts of Interest:

The author declare no conflict of interest. / Yazar, herhangi bir çıkar çatışması olmadığını beyan eder. 


\section{Kaynakça}

Abdulaziz el-Buhârî, Alâuddin Abdulaziz b. Ahmed. Keșfü'l-Esrâr Şerhu Usûli'l-Pezdevî. 4 Cilt. Mısır - Kahire: Dâru'l-Kitâbi'l-İslâmî, ts.

Abdulmecid b. Muhammed es-Sebîl. el-Ahkâmu'l-Fıkhiyye li-Nakli'l-A'dâi'l-İnsâniyye. Riyad: Dâru İbni'l-Cevzî, 1. Basım, 2016.

Abdunnâsır Ka'dân. "Zeru'l-A'dâi ve Ahlâkiyyeti't-Tıb min Manzûrin İslâmiyy". İnternet Forum. http://www.ishim.net/articles.htm, ts. https://www.ishim.net/ankaadan6/organtransplant.htm

Ahmed b. Hanbel. el-Müsned. thk. Şuayb el-Arnaût - Âdil Mürşid. 45 Cilt. Beyrut: Müessesetü'r-Risâle, 2001.

Akdemir, Hikmet. “Organ Naklinin Kur'an Açısından Değerlendirilmesi”. Harran Üniversitesi İlahiyat Fakültesi Dergisi 14 (2005), 7-13.

Arif Ali Arif el-Karadâĝî. Kadâyâ Fıkhiyye fî Nakli'l-A'dâi'l-Beșeriyye. Beyrut: Dâru'lKutubi'l-İlmiyye, 1. Basım, 2012.

Aynî, Bedreddin Mahmûd b. Ahmed. Şerhu Sünen-i Ebî Dâvûd. ed. Ebû'l-Münzir Hâlid b. İbrâhim. 7 Cilt. Riyad: Mektebetü'r-Rüșd, 1. Basım, 1999.

Beyhakî, Ebûbekir Ahmed b. Hüseyin b. Ali. Sünenül'l-kübrâ. Beyrut: Dâru'l-ma'rife, 1346.

Buhârî, Ebû Abdillah Muhammed b. İsmail. el-Camiu'l-Müsnedi's-Sahihi'l-Muhtasar min Umûri Rasûlillahi Sallâllahu Aleyhi ve Sellem ve Sünenihi ve Eyyâmih. thk. Muhammed Züheyr b. Nâsır. 6 Cilt. Mısır: Dârü Tavgü'n-Necât, 2001.

Diniz, Gülden. "Türkiye ve Dünyada Organ Transplantasyonu”. Tepecik Eğit. ve Arașt. Hast. Dergisi 29/1 (2019), 1-10. https://doi.org/10.5222/terh.2019.40412

Diyanet İşleri Başkanlığı Din İşleri Yüksek Kurulu. Fetvalar. Ankara: Diyanet İşleri Başkanlığı Yayınları, 4. Basım, 2018.

Dr. Behnan ALPER vd. "Ölüm”. Adli Otopsiler ve Adli Patoloji. Erişim 05 Eylül 2021. https://www.ttb.org.tr/eweb/adli/3.html

Ebû Dâvûd, Süleyman b. Eş'as es-Sicistânî. es-Sünen. thk. Muhyiddin Abdulhamid. 4 Cilt. Beyrut, Dârü'l-Kütübi'l-Arabî., ts.

Ebu'l-Esâd et-Tayyib Hasen, Muhammed. Maksadu Hifzi'n-Nefs ve Eseruhu fî Zırâati'lA'dâi'l-Beşeriyye. Endonezya: Malang Devlet Üniversitesi, 2015.

Fuâd b. Abdeh Ebu'l-Gays. "en-Nisbiyye ve't-Tegayyur ve Mezhebü'ş-Şekki'l-Mutlak". Mecelletü'l-Beyân 213 (ts.), 27.

Hasan Ali eş-Şâzelî. Hükmü Nakli A'dâi'l-İnsân fí Fıkhı'l-İslâmi. @univeyes.ebook · İnternet Sitesi: Mektebetü Ayni'l-Câmia, ts.

Hatîb el-Bağdâdî, Ebû Bekr Ahmed b. Alî. el-Fakîh ve'l-Mütefekkih. ed. Ebû Abdurrahman Âdil b. Yûsuf. 2 Cilt. el-Memleketü'l-Arabiyyetü's-Suûdiyye: Dârü İbni'l-Cevzî, 2001.

Haylamaz, Reşit. İslam Hukukuna Göre Organ ve Doku Nakli. Bursa: Bursa Uludağ Üniversitesi İlahiyat Fakültesi, 1992.

Heysemî, Ebu'l-Hasen Nureddin Ali b. Ebî Bekr. Mecmeu'z-Zevâid ve Menbeu'l-Fevâid. ed. Hüsameddin el-Kudsî. 10 Cilt. Kahire: Mektebetü'l-Kudsî, 1994.

İbn Abdülber, Ebû Ömer Cemâlüddîn Yûsuf b. Abdillâh en-Nemerî. et-Temhîd Limâ fi'lMuvatta. thk. Mustafa b. Ahmed el-Alevî - Muhammed Abdülkebîr. 24 Cilt. Mağrib: Vizâratü 'Umûmi'l-Evkâf ve'ş-Şuûni'l-İslamiyye, 1967.

İbn Ebî Şeybe, Ebû Bekir Abdullah b. Muhammed. el-Musannef fi'l-Ehâdîs ve'l-Âsâr. thk. Kemâl Yûsuf el-Hût. 7 Cilt. Riyâd: Mektebetü'r-Rüșd, 1989.

İbn Kayyım el-Cevziyye, Muhammed b. Ebî Bekr. Zâdü'l-Meâd fî Hedyi Hayri'l-İbâd. 5 Cilt. Beyrut: Müessesetu'r-Risâle, 27. Basım, 1994.

İbn Mâce, Ebû Abdillâh Muhammed b. Yezîd. es-Sünen. thk. Muhammed Fuâd Abdülbâkî. Kahire: Dârü'l-İhyâi'l-Kütübi'l-Arabiyye, ts. 
İbnü'l-Cevzî, Ebü'l-Ferec Cemâlüddîn Abdurrahman b. Ali. Keșfü'l-Müșkil min Hadisî’sSahîhayn. ed. Ali Hüseyn el-Bevvâb. 4 Cilt. Riyâd: Dâru'l-Vatan, ts.

İbnü'l-Esîr, Ebü's-Seâdât Mecdüddîn el-Mübârek b. Esîrüddîn. en-Nihâye fî Garîbi'l-Hadîsi ve'l-Eser. ed. Tâhir Ahmed ez-Zâvî. 5 Cilt. Beyrut: el-Mektebetü'l-İlmiyye, 1. Basım, 1979.

Karadâvî, Yusuf. el-Fetâvâl-Muâsıra. 3 Cilt. Mısır - İskenderiye: Dâru'l-Vefâ, 3. Basım, 1994.

Karaman, Fikret. "Organ Nakli ve Dini Boyutu Üzerine Bir Değerlendirme". Mesned Illahiyat Araştırmaları Dergisi 10/1 (2019), 9-33.

Leknevî, Muhammed Abdülhay el-. el-Ecvibetü'l-Fâdıla Li'l-Esileti'l-Aşarati'l-Kâmile. Kâhire: Mektebetü'l-Matbûâtü'l-İ́slâmiyye, 2. Basım, 1984.

Macit, Mustafa, Öztaş Fatih. “'Kalbinize Bir Sorun Hayat Vermek İster mi?' Kadavradan Organ Nakli ile İlgili Tutumlar, Tip ve Toplum (İnternet Gazete Haberleri Üzerinden Bir İnceleme)". ILTED (Illahiyat Tetkikleri Dergisi) 1/45 (2016), 27-44.

Mâlik b. Enes, Ebû Abdillâh. el-Muvatta. thk. Muhammed Fuâd Abdülbâkî. Beyrut: Müessesetü Zâyid b. Sultân, 1985.

Mansûr Abdullah ed-Düreys, Halid. Mevkifü'l-Imâmeyni'l-Buhârî ve Müslim min İștirâti'lLukyâ ve's-Semâ' fi's-Senedi'l-Mu'an'an beyne'l-Müteâsırayn. Riyad: Mektebetu'rRüşd, 1. Basım, 2005.

Mevsılî, Ebû Ya'lâ Ahmed b. Ali. el-Müsned. thk. Hüseyin Selîm Esed. 13 Cilt. Dimeșk: Dârü'l-Me'mûn li't-Türâs, 1984.

Muhammed Hasan Abdülgaffâr. Usûlü I'tikâdi Ehli's-Sünneti Ve'l-Cemâa. Mevkiu'şŞebeketi'l-İslâmiyye (http://www.islamweb.net), ts.

Muhammed Ra'fet Osman. "Naklü ve Zer'ü'l-A'dâ". Zirâatü ve Maklü'l-A'dâ. 1-31. Mısır: elEzherü'ş-Șerîf, 2009.

Muhammed Raşid Kubbânî. “Zırâatü'l-A'dâi'l-İnsaniyye fî Cismi'l-İnsan”. Mecelletü'lMecmei'l-Fıkhi'l-İslâmî 1/1 (2003), 55-65.

Münâvî, Muhammed Abdürraûf. Feyzü'l-Kadîr Şerhü Câmii's-Sağîr. 6 Cilt. Mısır: Mektebetü't-Ticâriyyeti'l-Kübrâ, 1. Basım, 1938.

Müslim, Ebü'l-Hasen Müslim b. Haccâc el-Küșeyrî. el-Müsnedü's-Sahîhi'l-Muhtasar bi Nakli'l-Adli ani'l-Adli İlâ Rasûlillahi Sallallahu Aleyhi ve Sellem. thk. Muhammed Fuad Abdulbâki. 5 Cilt. Beyrut: Dârü İhyâi't-Türâsi'l-Arabî, ts.

Nesâî, Ebû Abdirrahmân Ahmed b. Şuayb. es-Sünen (el-Müctebâ). thk. Abdülfettâh Ebû Gudde. 9 Cilt. Halep: Mektebü'l-İslamiyye, 2. Basım, 1986.

Özdemir, Merve. İslam Hukukuna Göre Beden Üzerinde Tasarruf ve Organ Nakli. Sakarya Üniversitesi, 2017.

Özşaker, Esma. "Organ Nakli ve Yaşam Kalitesi”. Balıkesir Sağlık Bilimleri Dergisi 3/3 (Aralık 2014), 166-173. https://doi.org/10.5505/bsbd.2014.98598

Râgıb el-İsfahânî, Ebü'l-Kāsım Hüseyn b. Muhammed. el-Müfredât fî Garîbi'l-Kur'an. ed. Safvân Adnân ed-Dâvudi. Dımaşk - Beyrut: Dâru'l-kalem - Dâru'ş-Şâmiye, 1. Basım, 1992.

Sabâh, Mâzin Misbâh. "Kâidetü ed-Darar Yüzâlü - Hücciyyetühâ ve Davâbituhâ". Mecelletü'l-Adl 67 (ts.), 202-282.

Saîd b. Mansûr, Ebû Osmân. Sünen-i Saîd b. Mansûr. ed. el-A'zamî Habîbürrahmân. Hindistan: ed-Dâru's-Selefiyye, 1. Basım, 1982.

San'ânî, Abdürrezzâk Ebû Bekir b. Hemmâm. el-Musannef. thk. el-A'zamî Habîbürrahmân. 11 Cilt. Beyrut: el-Mektebü'l-İslamî, 1983.

Selma Bıyıklı Adabaș. "Beyin Ölümüne 4 Yerine 2 Hekim Karar Verecek". Anadolu Ajansı (04 Ocak 2014). https://www.aa.com.tr/tr/saglik/beyin-olumune-4-yerine-2hekim-karar-verecek/193004

Sid, Roumaissa. Müsteciddâtü Nakli'l-A'dâi fi Manzûri'l-Fıkhi'l-İslâmî (Organ naklindeki yeni gelişmelerin İslam Hukukuna göre değerlendirilmesi). Konya: Necmettin Erbakan Üniversitesi, 2019. 
Subkî, Tâcuddin Abdulvehhab b. Tekuyyiddin es-. el-Eşbâh ve'n-Nezâir. 2 Cilt. Beyrut: Dârü'l-Kütübi'l-'ilmiyye, 1. Basım, 1991.

Süyûtî, Abdurrahman Celâlüddin es-. el-Lüma' fî Esbâbi Vurûdi'l-Hadîs. 1 Cilt. Beyrut: Dâru'l-Fikr, 1. Basım, 1996.

Șener, Mehmet. "İslam Hukukuna Göre Organ Nakli Üzerine Bir Deneme". Dokuz Eylül Üniversitesi İlahiyat Fakültesi Dergisi 7 (1992), 137-146.

Taberânî, Ebü'l-Kâsım Süleyman b. Ahmed. el-Mu'cemü'l-Kebîr. thk. Hamdi b. Abdilmecîd. 25 Cilt. Musul: Mektebetü'l-'Ulûm ve'l-Hikem, 3. Basım, 1983.

Tayâlisî, Ebû Dâvûd Süleyman b. Dâvûd. el-Müsned. thk. Muhammed b. Abdülmühsin etTürkî. 4 Cilt. Mısır: Dârü Hicr, 1. Basım, 1999.

Tirmizî, Ebû Îsâ Muhammed b. Îsâ. el-Câmiü's-Sahîh (es-Sünen). thk. Beşşâr Avvâd Ma'rûf. 6 Cilt. Beyrut: Dârü'l-Garbi'l-İslamî, 1998.

Türkiye Cumhuriyeti Sağlık Bakanlığı. "Organ ve Doku Nakli Hizmetleri Yönetmeliği”. Resmi Gazate. T.C. Cumhurbaşkanlığı Mevzuat Bilgi Sistemi, 01 Şubat 2012. https://www.mevzuat.gov.tr/mevzuat?MevzuatNo=15860\&MevzuatTur=7\&Mev zuatTertip $=5$

Ünverdi, Mustafa. "Yeniden Dirilişin Keyfiyeti Bakımından Organ Nakli". Dinbilimleri Akademik Araștırma Dergisi 15/1 (2015), 43-70.

Yavuz, Yusuf Şevki. "Acbü'z-Zeneb”. 1/319-320. İstanbul: Türkiye Diyanet Vakfı Yay., 1988.

Zemahşerî, Ebü'l-Kāsım Mahmûd b. Ömer. el-Keșşâf an Hakâiki Gavâmidi't-Tenzîl. 4 Cilt. Beyrut: Dâru'l-Kitâbi'l-Arabî, 3. Basım, ts.

Zeydân, Abdülkerim. el-Vecîz fí Şerhi'l-Kavâidi'l-Fıkhiyye. 1 Cilt. Beyrut: Müessesetu'rRisâle, 1. Basım, 2009.

Zeylaî, Cemâlüddin Ebû Muhammed Abdullah b. Yusuf. Tahrîcü'l-Ehâdîsi ve'l-Âsâri'l-Vâkı fî Tefsîri'l-Keş̧̦âf li'z-Zemahşerî. ed. Abdullah b. Abdurrahman es-Sa'd. 4 Cilt. Riyad: Dâru İbn Hüzeyme, 1. Basım, 1993.

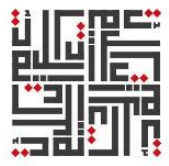

